\title{
Signaling in and out: long-noncoding RNAs in tumor hypoxia
}

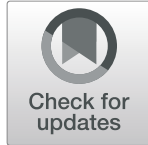

Tse-Chun Kuo', Hsing-Jien Kung ${ }^{1,2,3,4,5}$ and Jing-Wen Shih ${ }^{2,3,5,6^{*}}$ (D)

\begin{abstract}
Over the past few years, long non-coding RNAs (IncRNAs) are recognized as key regulators of gene expression at chromatin, transcriptional and posttranscriptional level with pivotal roles in various biological and pathological processes, including cancer. Hypoxia, a common feature of the tumor microenvironment, profoundly affects gene expression and is tightly associated with cancer progression. Upon tumor hypoxia, the central regulator HIF (hypoxia-inducible factor) is upregulated and orchestrates transcription reprogramming, contributing to aggressive phenotypes in numerous cancers. Not surprisingly, IncRNAs are also transcriptional targets of HIF and serve as effectors of hypoxia response. Indeed, the number of hypoxia-associated IncRNAs (HALs) identified has risen sharply, illustrating the expanding roles of IncRNAs in hypoxia signaling cascade and responses. Moreover, through extracellular vesicles, IncRNAs could transmit hypoxia responses between cancer cells and the associated microenvironment. Notably, the aberrantly expressed cellular or exosomal HALs can serve as potential prognostic markers and therapeutic targets. In this review, we provide an update of the current knowledge about the expression, involvement and potential clinical impact of IncRNAs in tumor hypoxia, with special focus on their unique molecular regulation of HIF cascade and hypoxia-induced malignant progression.
\end{abstract}

Keywords: Tumor hypoxia, Long non-coding RNA, IncRNA, HIF-1a, Hypoxia-associated IncRNAs, HAL, Extracellular vesicles

\section{Background}

Hypoxia-associated IncRNAs (HALs) emerging as newly driving factors in tumorigenesis

In rapidly growing solid tumors, hypoxia is a common, microenvironmental characteristics, caused by insufficient vascularization, and the high tumor metabolic demands [1]. Accumulating evidence has demonstrated that tumor hypoxia is involved in the initial oncogenic transformation, but is also tightly linked to aggressive cancer phenotypes, such as metastases, recurrences and resistance to

\footnotetext{
* Correspondence: shihjw@tmu.edu.tw

${ }^{2}$ Graduate Institute of Cancer Biology and Drug Discovery, College of Medical Science and Technology, Taipei Medical University, Taipei 11031, Taiwan, ROC

${ }^{3}$ Ph.D. Program for Cancer Biology and Drug Discovery, College of Medical Science and Technology, Taipei Medical University, Taipei 11031, Taiwan, ROC

Full list of author information is available at the end of the article
}

therapy [2-4]. Upon hypoxia, to survive, cancer cells coopt the fundamental adaptive responses to this stress through modulating the central mediator of hypoxic response, the hypoxia-inducible factor-1 (HIF-1) complex.

The HIF-1 complex is a heterodimeric assembly of bHLH-PAS (basic helix-loop-helix DNA binding proteins of the PER-ARNT-SIM family) transcriptional factors, comprised of a constitutively expressed, stable HIF-1 $\beta$ subunit and an oxygen-sensitive HIF- $1 \alpha$ subunit that determines HIF-1 activity [5, 6]. In mammals, two HIF- $1 \alpha$ homologs, HIF-2 $\alpha$ and HIF-3 $\alpha$ (also known as IPAS-1; inhibitory PAS (Per/Arnt/Sim) domain protein), have been identified. Similar to HIF-1 $\alpha$, HIF- $2 \alpha$ is also sensitive to oxygen concentration and can interact with HIF- $1 \beta$ to form the HIF-2 heterodimeric complex. Due to the structural similarity in DNA binding and dimerization domains as well as the difference in their transactivation domains, 
HIF- $1 \alpha$ and HIF- $2 \alpha$ regulate both common as well as distinct sets of target genes. Meanwhile, HIF-3 $\alpha$, an isoform lacking the transactivation domain, has a dominant negative effect on HIF-dependent gene transcription $[7,8]$.

In the presence of sufficient oxygen, HIF-1 $\alpha$ subunits are post-translationally modified by a family of dioxygenases (prolyl hydroxylase domain-containing dioxygenases PHD1, 2 and 3, also known as EGLN1-3, Egl-9 family hypoxia inducible factor 1-3,). Upon hydroxylation, HIF-1 $\alpha$ subunits are recognized by the E3 ubiquitin ligase, VHL (von Hippel-Lindau tumor suppressor protein), leading to the poly-ubiquitination and subsequent rapid degradation through the ubiquitin-proteasome pathway (Fig. 1a). Under hypoxic conditions, the PHD dioxygenase activity is inhibited, and the accumulated HIF- $1 \alpha$ subunit translocates into the nucleus, dimerizing with HIF- $1 \beta$ and binding to the HREs (hypoxia response elements; the consensus 5 '-(A/ G)CGTG-3' nucleotide sequence) within the promoter regions of HIF target genes to stimulate downstream transcriptional activation of multiple hypoxia responsive genes (Fig. 1a), eliciting a wide spectrum of cellular adaptations, such as decreased apoptosis, enhanced angiogenesis, proliferation, migration and invasion [1,9-11]. In addition to protein coding genes, it has been widely acknowledged that the non-coding transcriptome is also responsive to hypoxia and play critical roles in the hypoxic response and HIF-1 associated cancer progression [12-16].

With recent advances in high-throughput sequencing, it is recognized that only a small fraction $(<2 \%)$ of the transcriptional output encodes proteins whereas the vast majority encode a variety of non-coding RNAs. Among these non-coding RNA species, long (>200 bp) non-coding RNAs (lncRNAs) are a large class of regulatory transcripts [17], including lincRNAs (long intergenic RNAs), long intronic ncRNAs, pseudogenes, TCRs (transcribed ultraconserved regions), asRNAs (antisense RNAs) and eRNAs (enhancer RNAs) [18]. According to the latest human genome annotation (GRch38, GENCODE release 33, January 2020; www.gencodegenes.org), 48,438 transcripts originating from 17,952 loci were identified as lncRNAs. Although less than $1 \%$ has been functionally annotated, growing evidence suggested the vital roles of these lncRNAs in regulation of gene expression at various stages, such as imprinting, transcription, RNA interference, RNA splicing, and translation control [19-23]. It is now believed that the distinctive RNA biochemical properties, such as base-pairing ability, dynamic expression and flexible structure, endow these IncRNAs with multi-functionality [24-28]. Collectively, it is now well appreciated that, through acting as signals, decoys, guides or scaffolds, lncRNA could act as a crucial player of biological regulation [23-25, 27, 29-33].

Over the last few years, a large number of dysregulated lncRNAs have been associated with numerous diseases, including cancer [34-37]. While a few cancer-associated
IncRNAs have been well characterized [27, 38], the functions of most remain largely unknown. Dysregulation of many cancer-associated lncRNAs is linked to both clinicopathological features and survival outcomes of patients, suggesting that functional annotation of these lncRNAs will eventually identify new venues for early diagnosis and therapy of cancer [39]. Several studies have shown that the modulation of lncRNAs in response to hypoxia could play a regulatory role in HIF signaling cascade [14-16, 40, 41]. Here, we refer to these unique transcripts as "hypoxia-associated lncRNAs" (HALs). These RNA molecules are involved in multiple hypoxiadriven cancer progression pathways. In this review, we provide an updated summary of the tumor HALs, with a specific emphasis on the crosstalk between these lncRNA species and cellular hypoxia response (Table 1 and Additional file 1: Table S1). We address current models describing the functional involvement of these new players in cancer progression, highlighting their relevant clinical potential as cancer biomarkers or therapeutic targets. Our discussion is centered on tumor hypoxia. For the functional roles of lncRNAs in hypoxia-induced kidney/hepatic/myocardial injury and neuromuscular or cardiovascular diseases, interested readers are referred to a number of comprehensive reviews published in recent years [127-132].

\section{Review}

\section{LncRNAs as emerging driving forces in cancer progression upon tumor hypoxia}

Given the pivotal roles of IncRNA in hypoxia-associated tumorigenesis pathways, multiple approaches have been applied in the identification of hypoxia-regulated lncRNAs [87, 90]. A comprehensive analysis coupling RNA-seq with ChIP-seq [12] revealed the extensive involvement of HIF- $1 \alpha$ and HIF- $2 \alpha$ in the transcriptional regulation of lncRNAs upon hypoxia. In recent years, the rapid expansion of research on lncRNAs has provided additional insights into those associated with cellular hypoxia response. Table 1 presents an updated list of these hypoxia-associated lncRNAs (HALs). Upon hypoxia, most HALs are up-regulated. HIF could directly promote the expression of these hypoxiainducible lncRNAs through binding to the HREs (hypoxia response elements) located in their promoter (Table 1) [41]. IncRNA-LET [93], CF129 [54] and CRPAT4 [56] are among the few which are down-regulated in hypoxic conditions. Notably, IncRNA-SARCC is able to respond to hypoxic stress differentially in a VHL-dependent manner [94].

Most of the HALs identified have impacts on cancer progression, although the mechanistic details are not all clear. Table 1 shows an overview of the tumor HALs. We summarize in the table, their potential molecular target related to hypoxic responses as well as their reported functions and signaling pathways. These HALs 
a

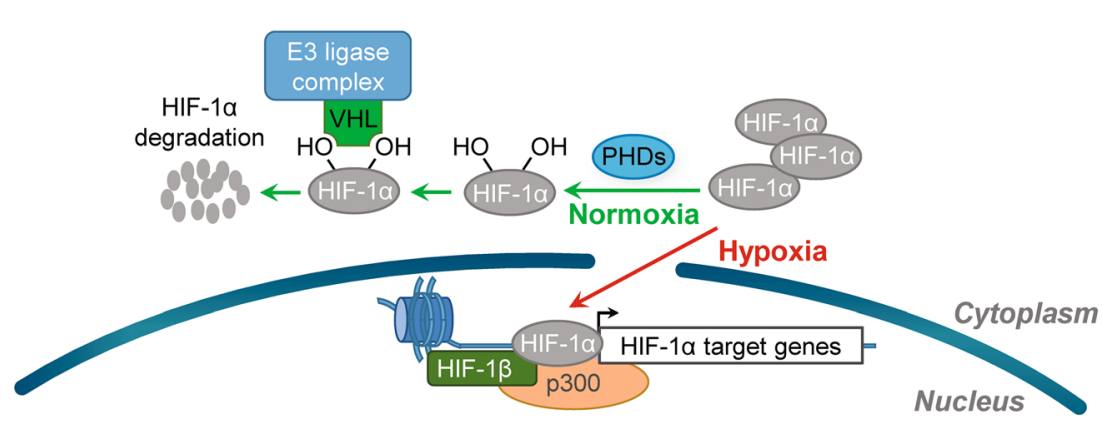

b

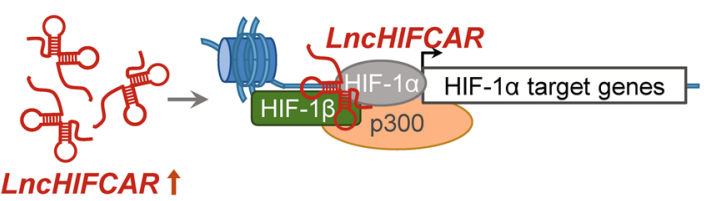

d

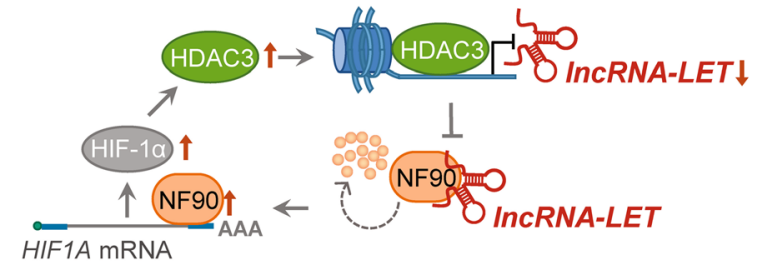

f

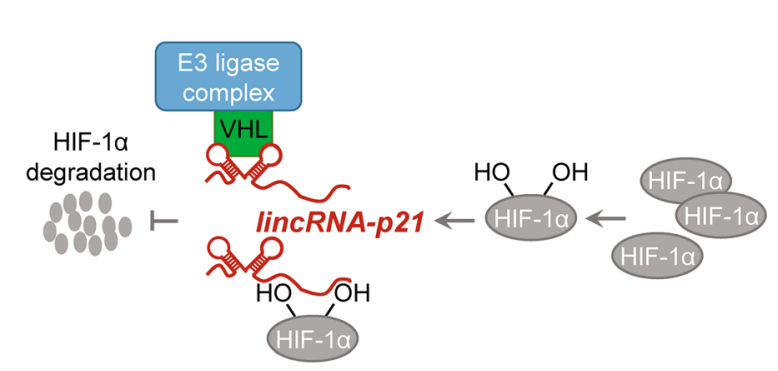

C

e
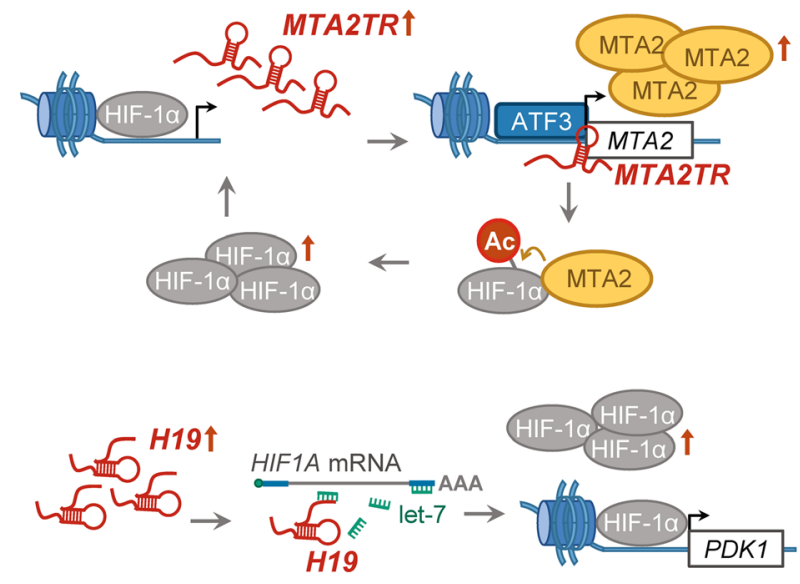

g

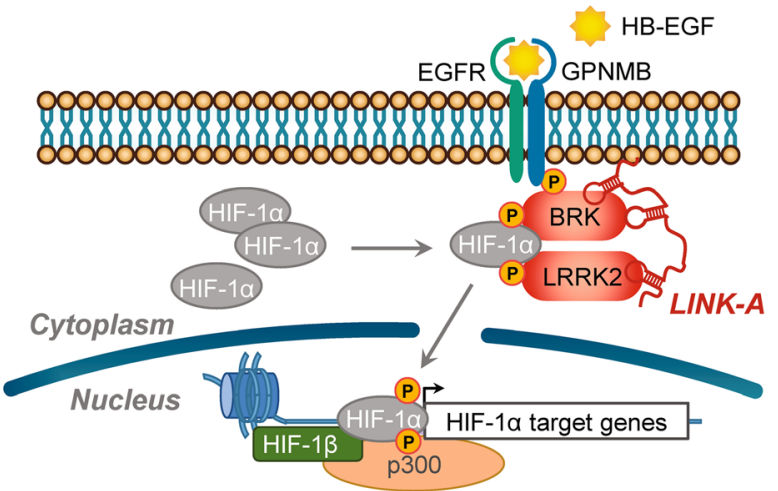

Fig. 1 Regulations of HIF-1 activity by HALs. a Regulation of HIF-1. Under normoxia (green arrows), HIF-1a subunit is hydroxylated by PHDs (prolyl hydroxylase domain proteins). Hydroxylation residues within HIF-1a facilitates interaction of HIF-1a with the E3 ubiquitin ligase VHL protein, targeting HIF-1a for polyubiquitination and subsequent proteasome-dependent degradation. Upon hypoxia (red arrows), the PHDs and other prolyl hydroxylases are inhibited, leading to HIF-1a stabilization and translocation into nucleus. After dimerization with its transcriptional partner HIF-1 $\beta$ and recruitment of co-activators (e.g. CBP/ p300), the HIF-1 heterodimer binds the HRE (hypoxia response element) of target genes to regulate transcription. b Transcriptional co-activator. Hypoxiainduced LnCHIFCAR could directly interact with HIF-1a and facilitate the recruitment of HIF-1a and p300 cofactor to the target loci, thereby upregulating HIF-1 target genes. c Recruitment of transcription factor. HIF-1a-induced LnCRNA-MTA2TR could recruit ATF3 to the promoter area of MTA2, thereby transcriptionally upregulating the expression of oncogenic MTA2. MTA2 can subsequently enhance HIF-1a protein accumulation via deacetylation, forming a feedback loop to amplify HIF-1 signaling. $\mathbf{d}$ mRNA stability control. The expression of InCRNA-LET is repressed through hypoxia-induced HDAC3, which reduces the histone H3 and $\mathrm{H} 4$ acetylation at the LnCRNA-LET promoter. Decreased InCRNA-LET expression reduces the InCRNA-LET-mediated degradation of HIF-1 a negative regulator, NF90, leading to HIF-1 a accumulation. e ceRNA/miRNA sponge. Hypoxia-induced H19 could upregulate HIF-1a expression by absorbing miRNA let-7 and nullifying let-7-mediated HIF1A mRNA suppression. f Molecular decoy. lincRNA-p21 is able to disrupt the interaction between HIF-1a and its negative regulator VHL via separate binding to both HIF-1a and VHL, thereby blocking VHL-dependent HIF-1a degradation. g Complex scaffold. LINK-A-mediated recruitment and enzymatic activation of BRK and LRRK2 kinases could facilitate phosphorylation of HIF-1a at specific residues. These phosphorylation modifications prevent subsequent HIF-1a degradation and enhance the association between HIF-1a and cofactor p300, thereby upregulating HIF-1 target genes. See text for a more detailed discussion 


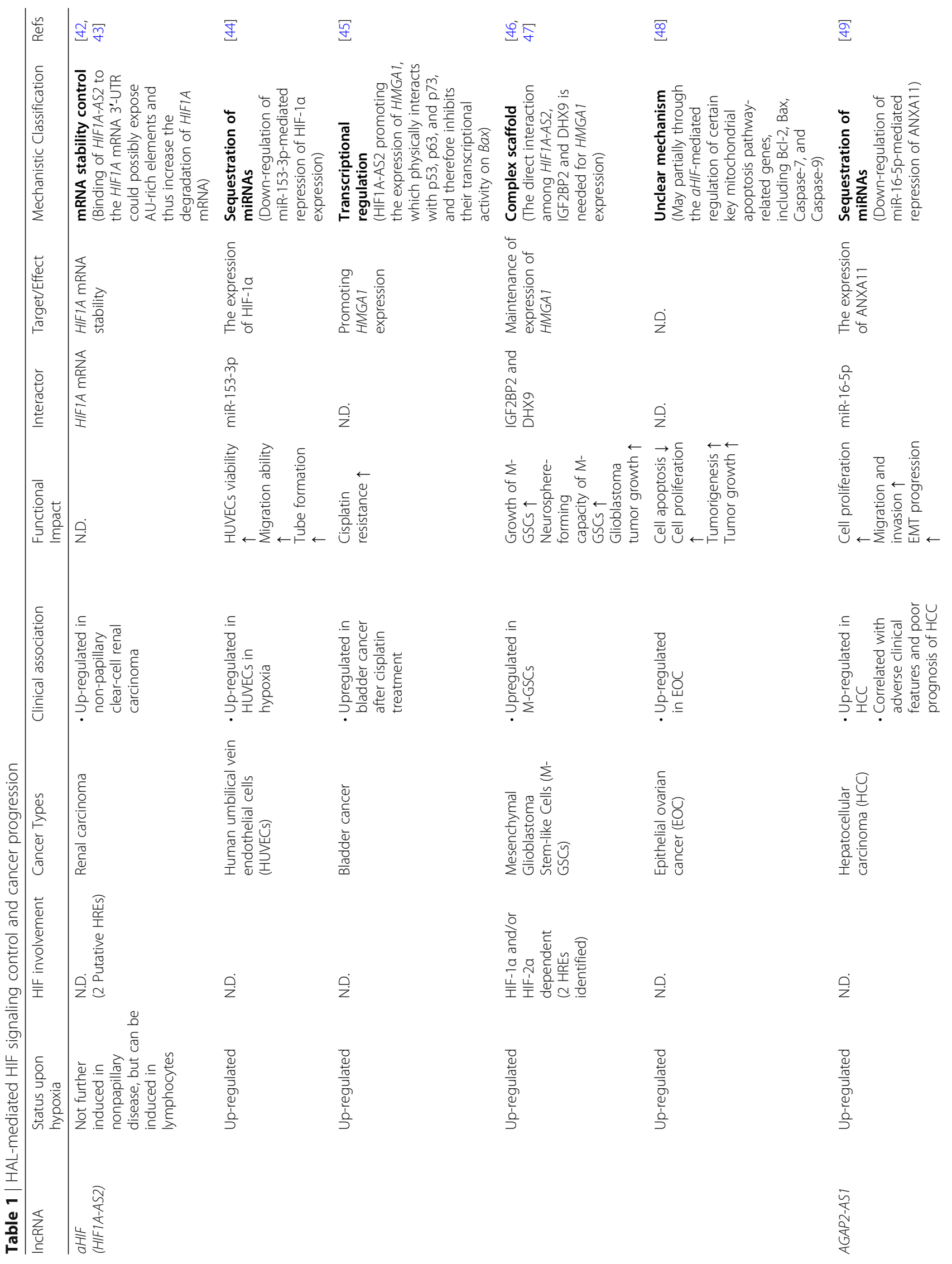




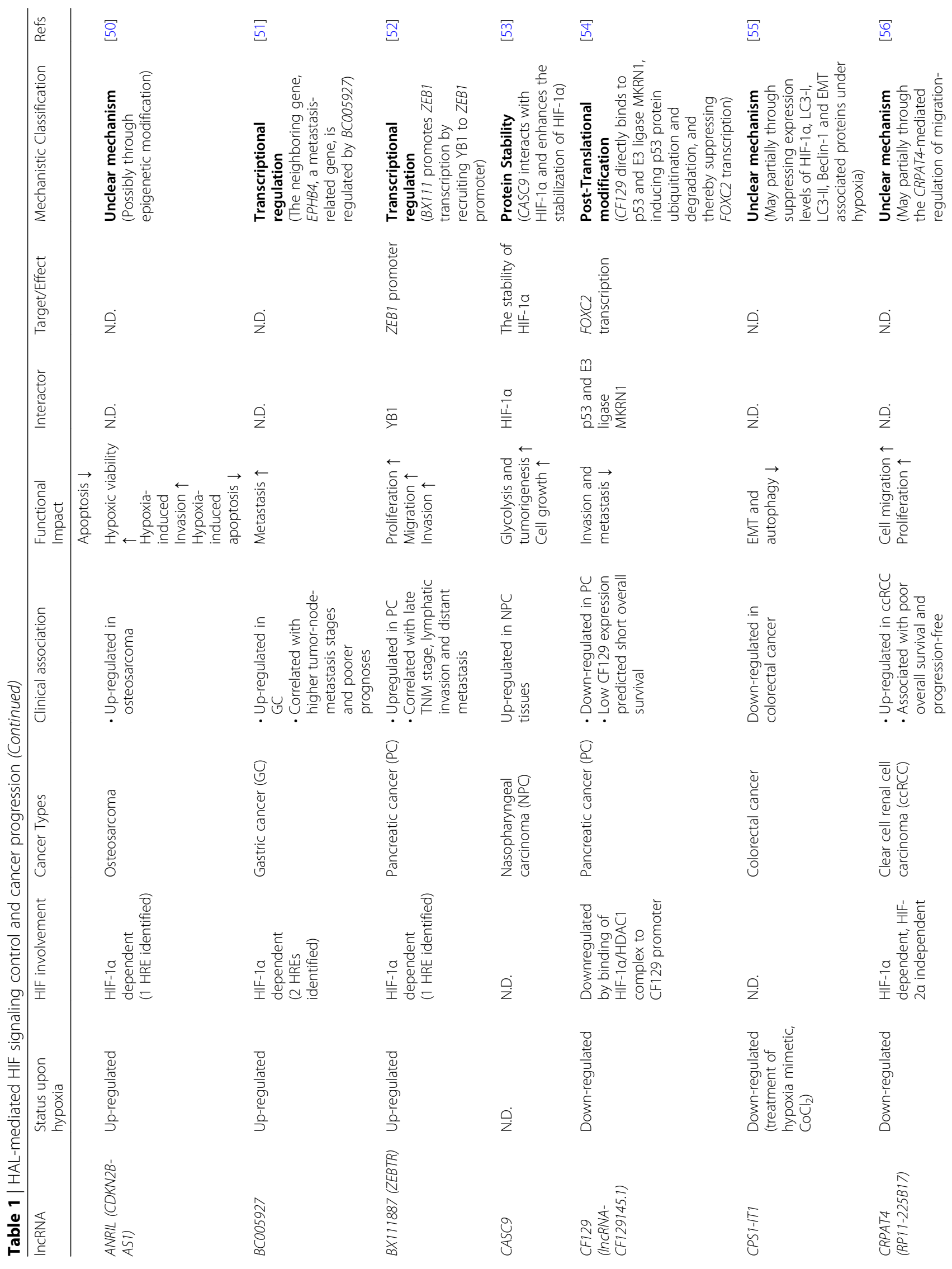




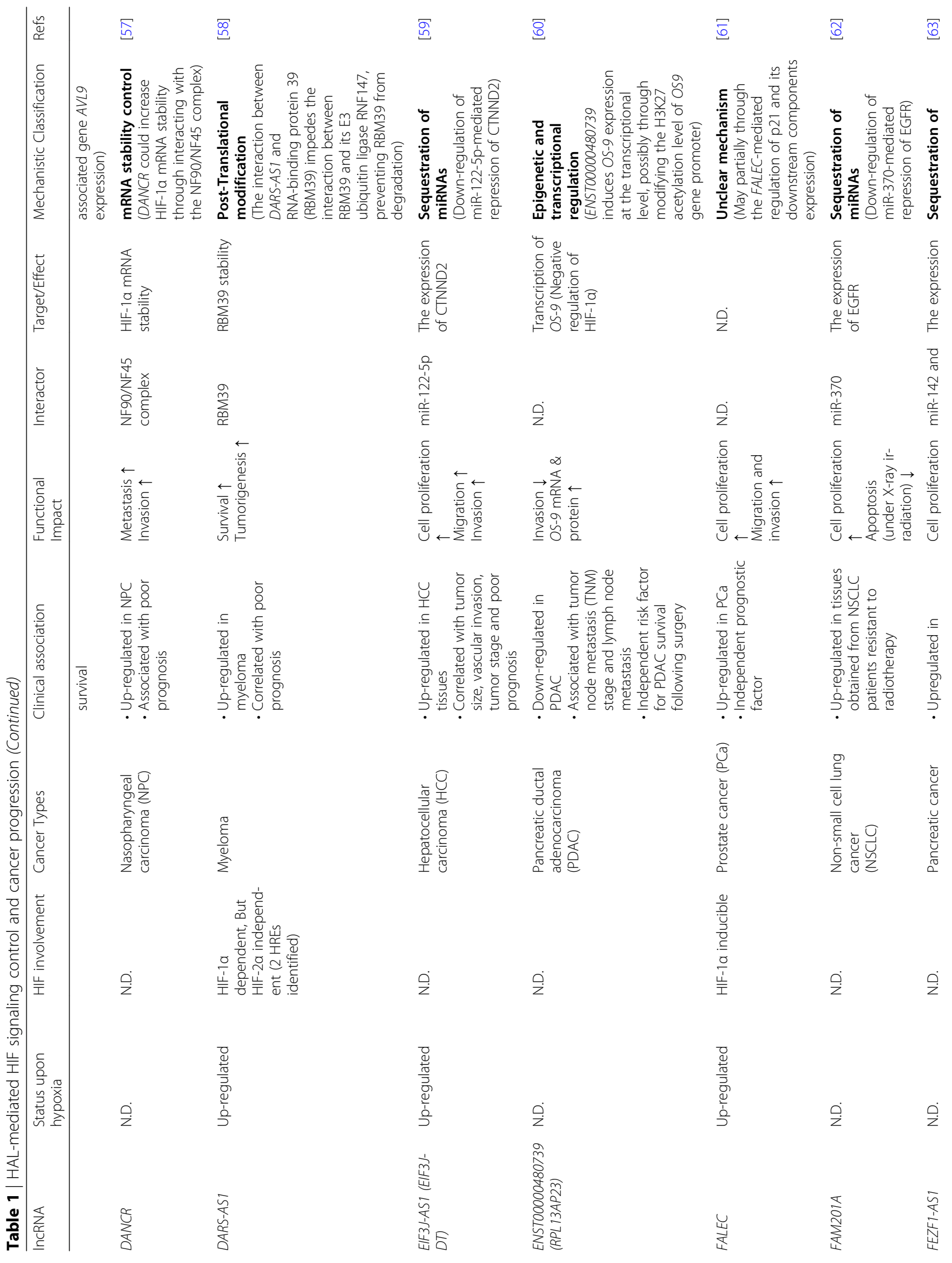




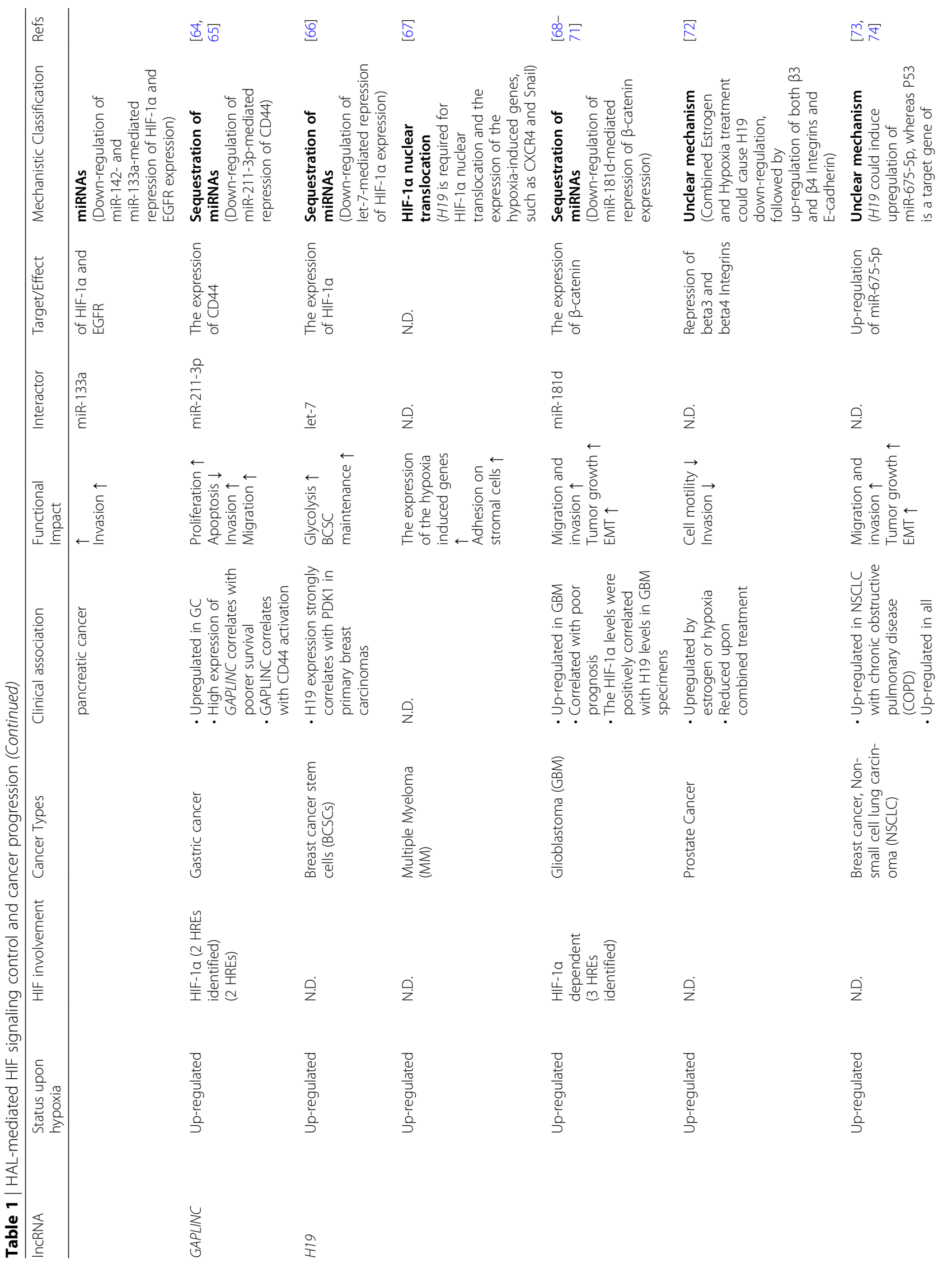




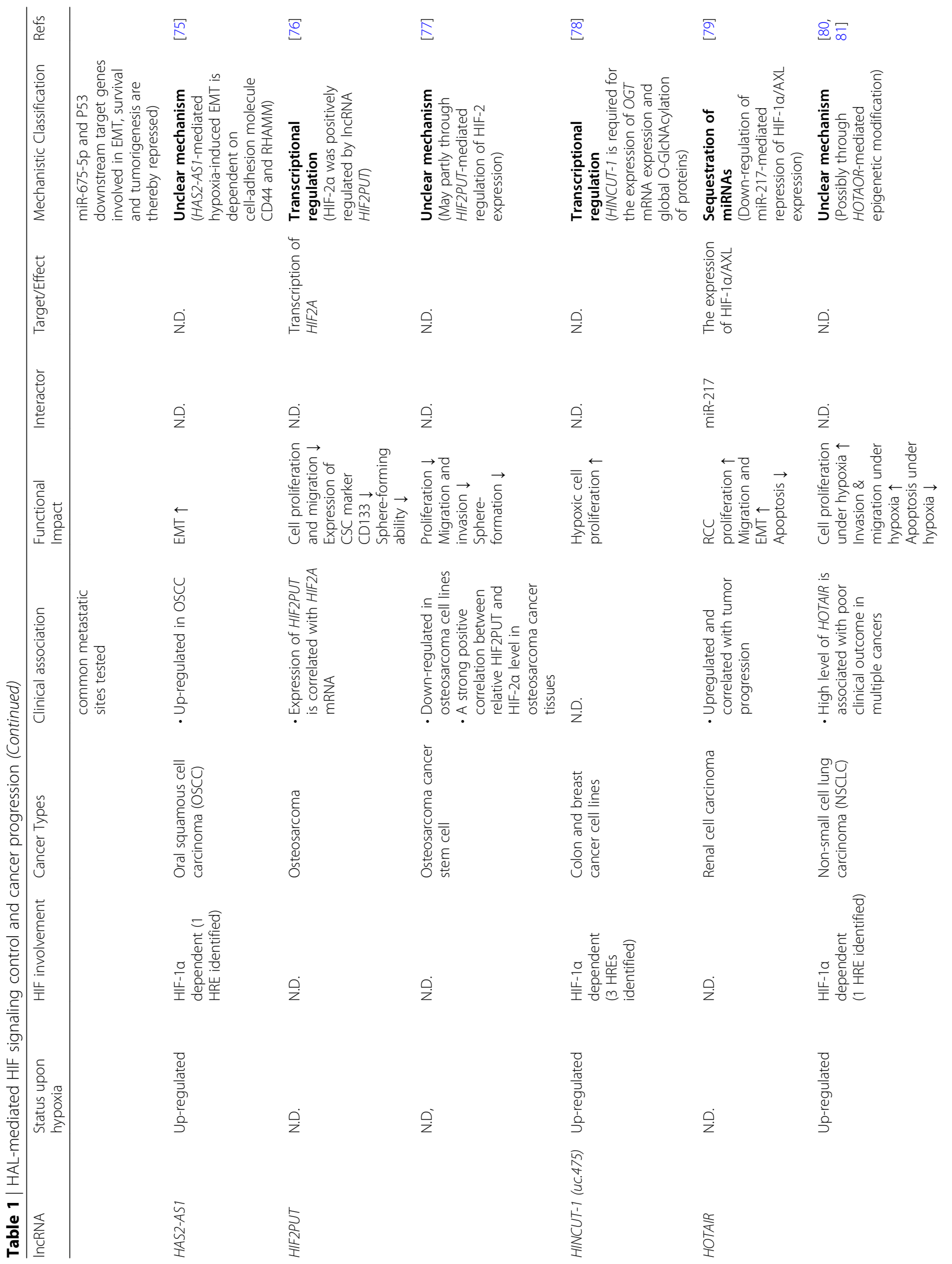




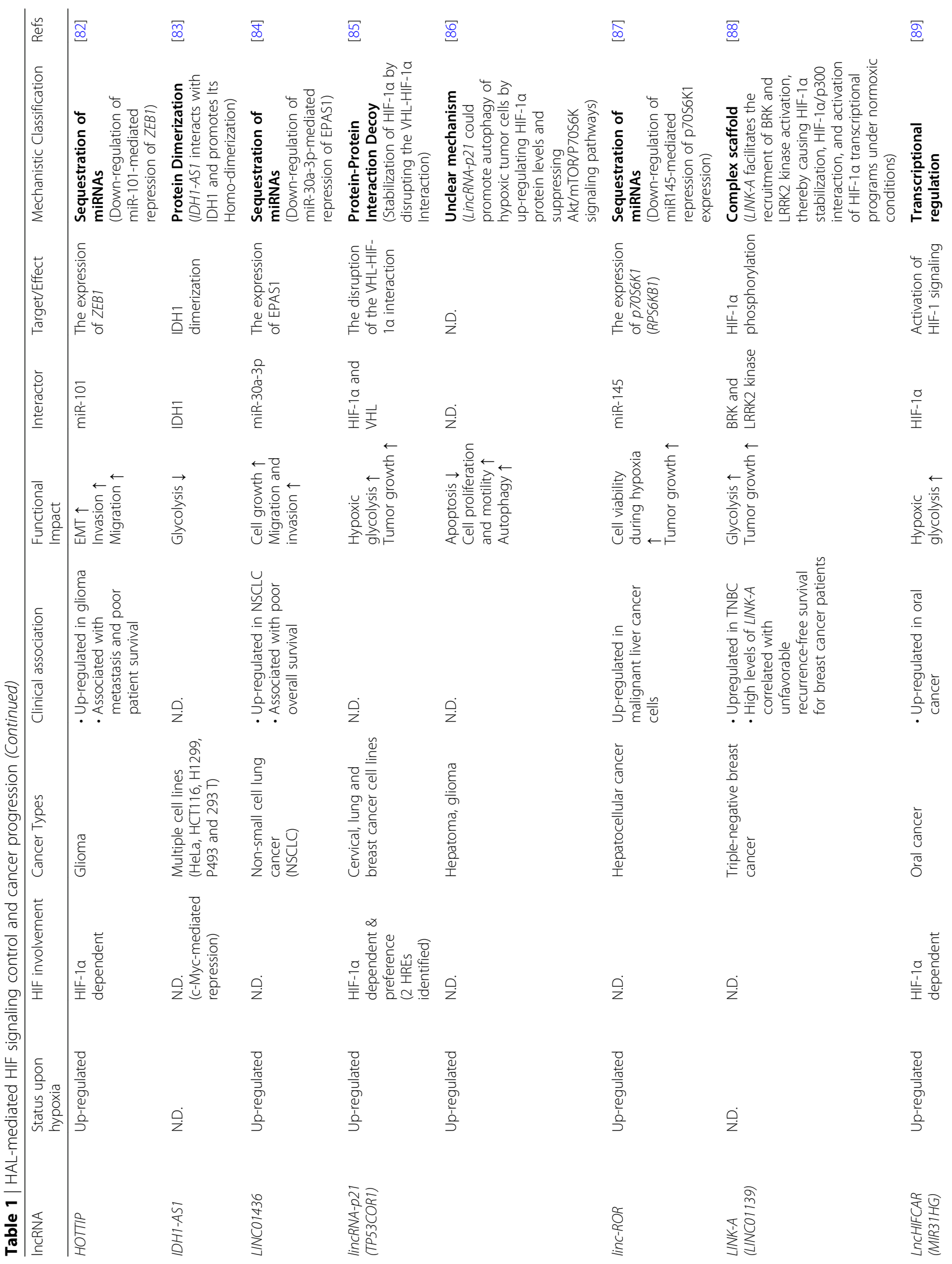




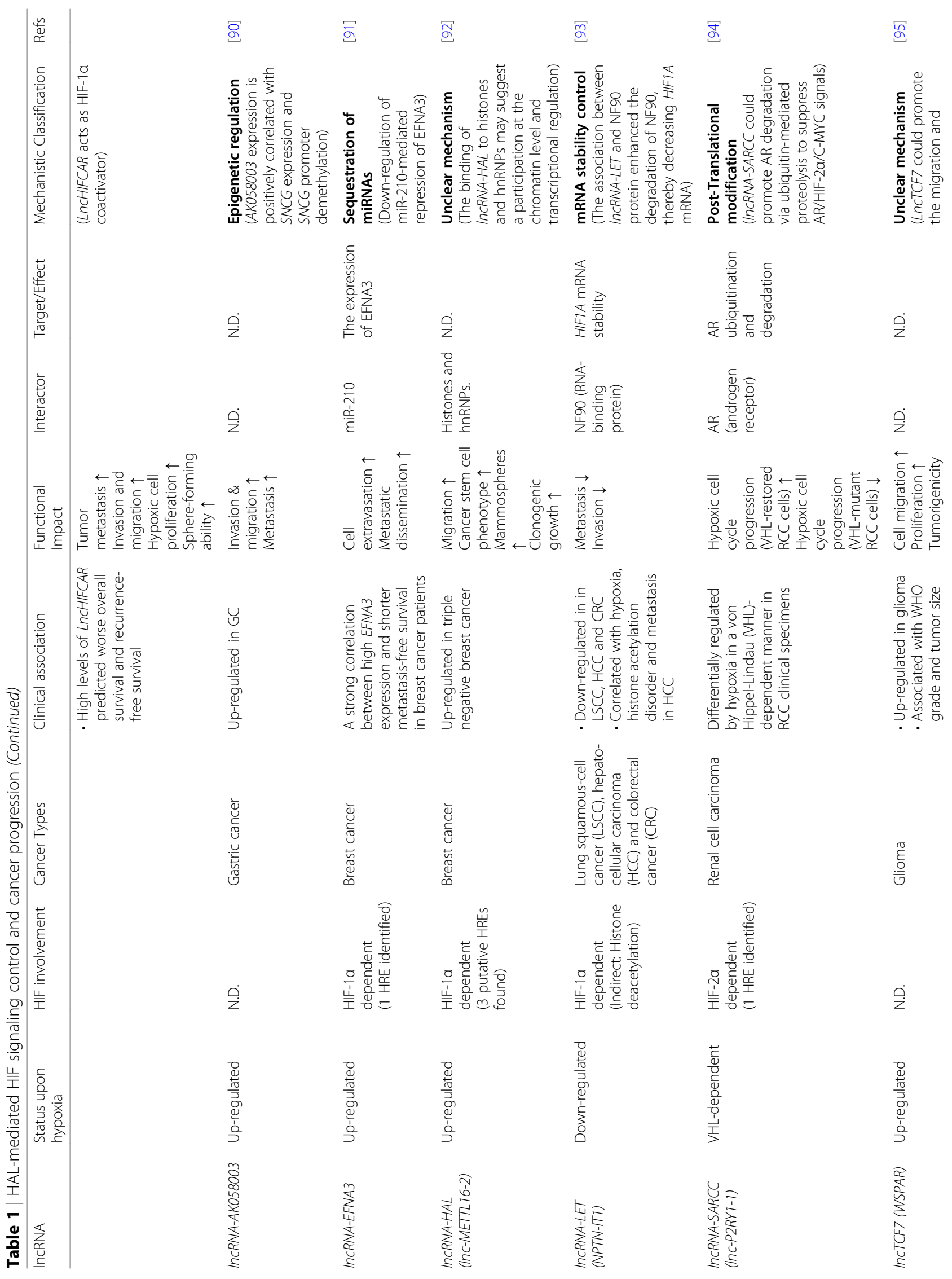




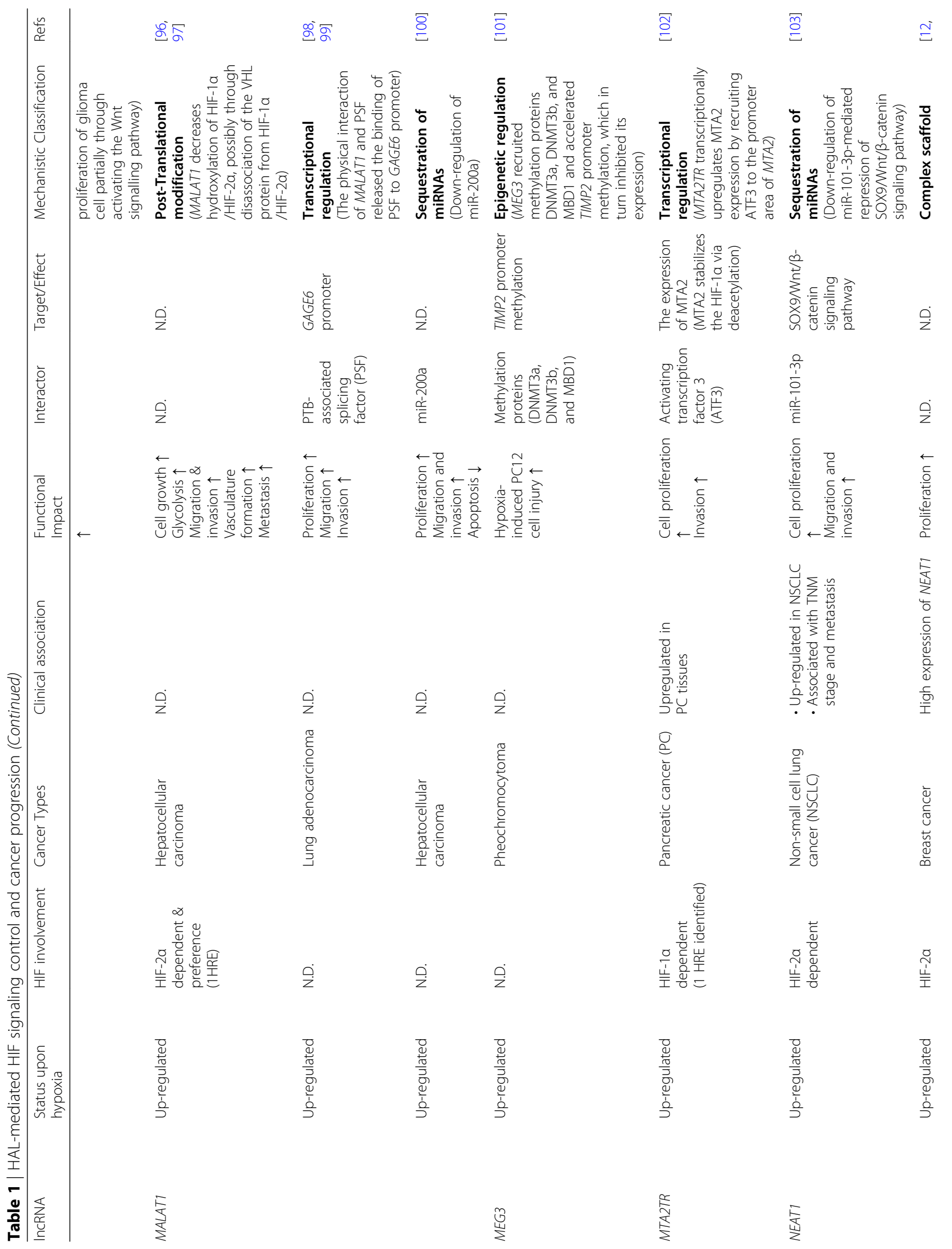




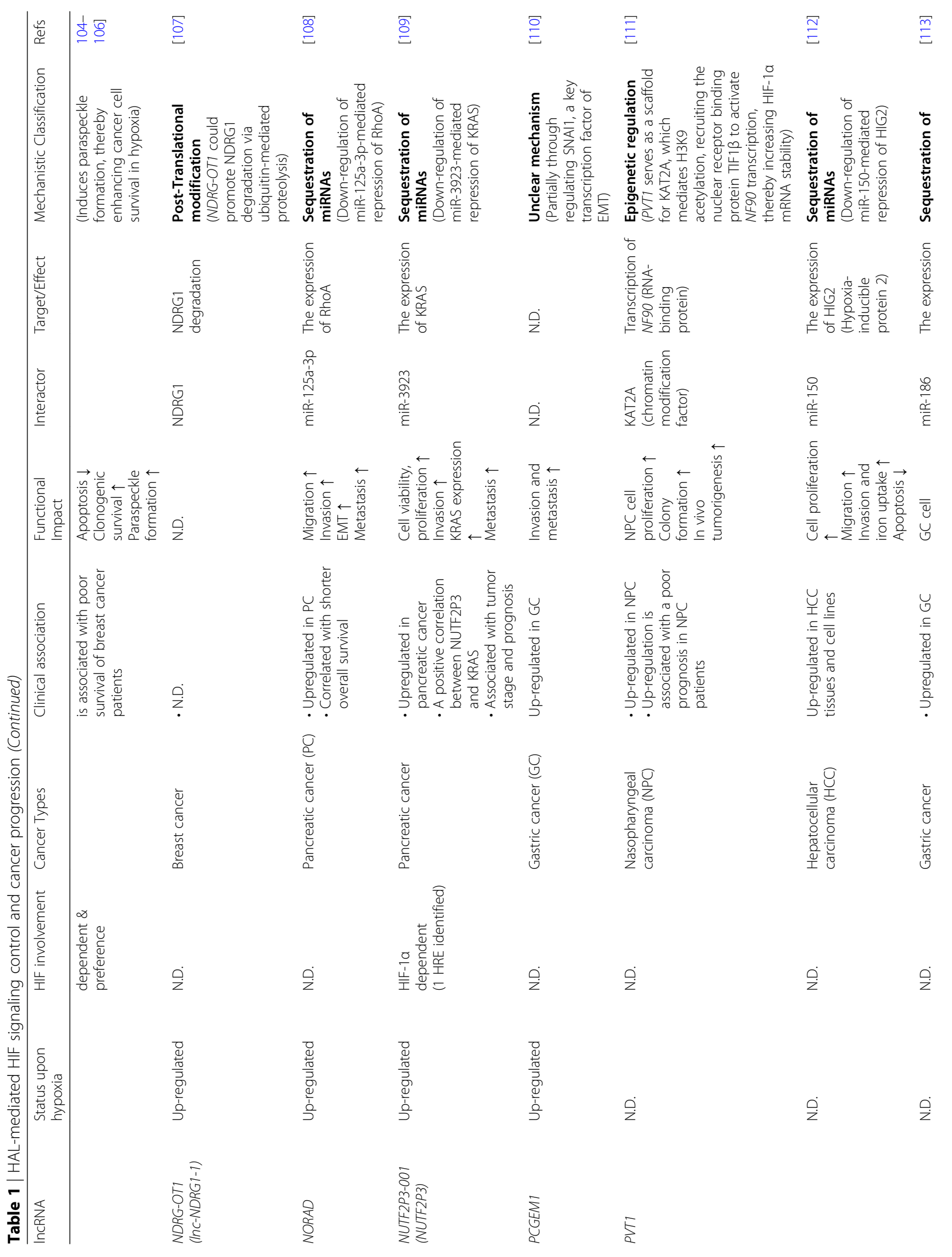




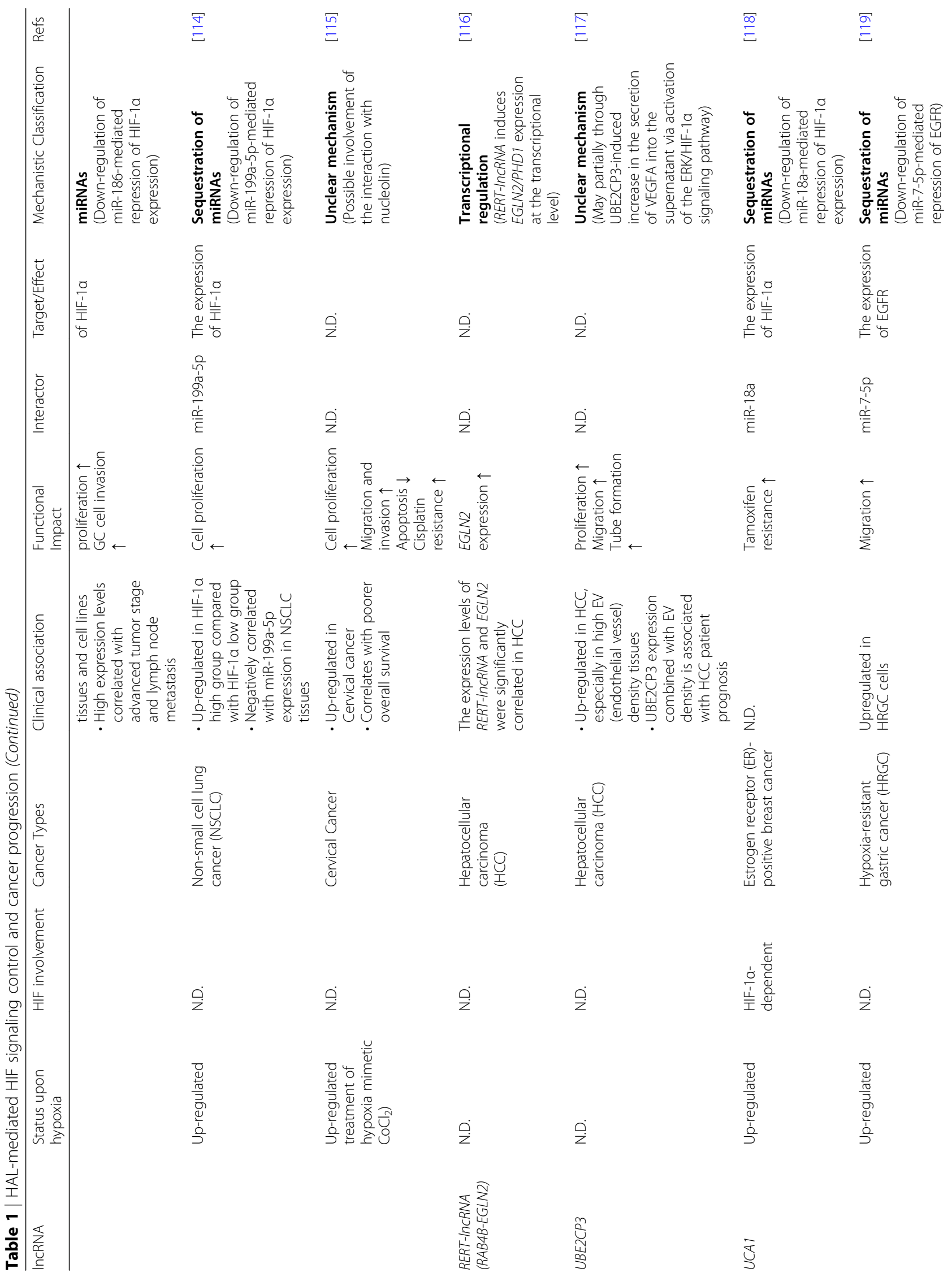




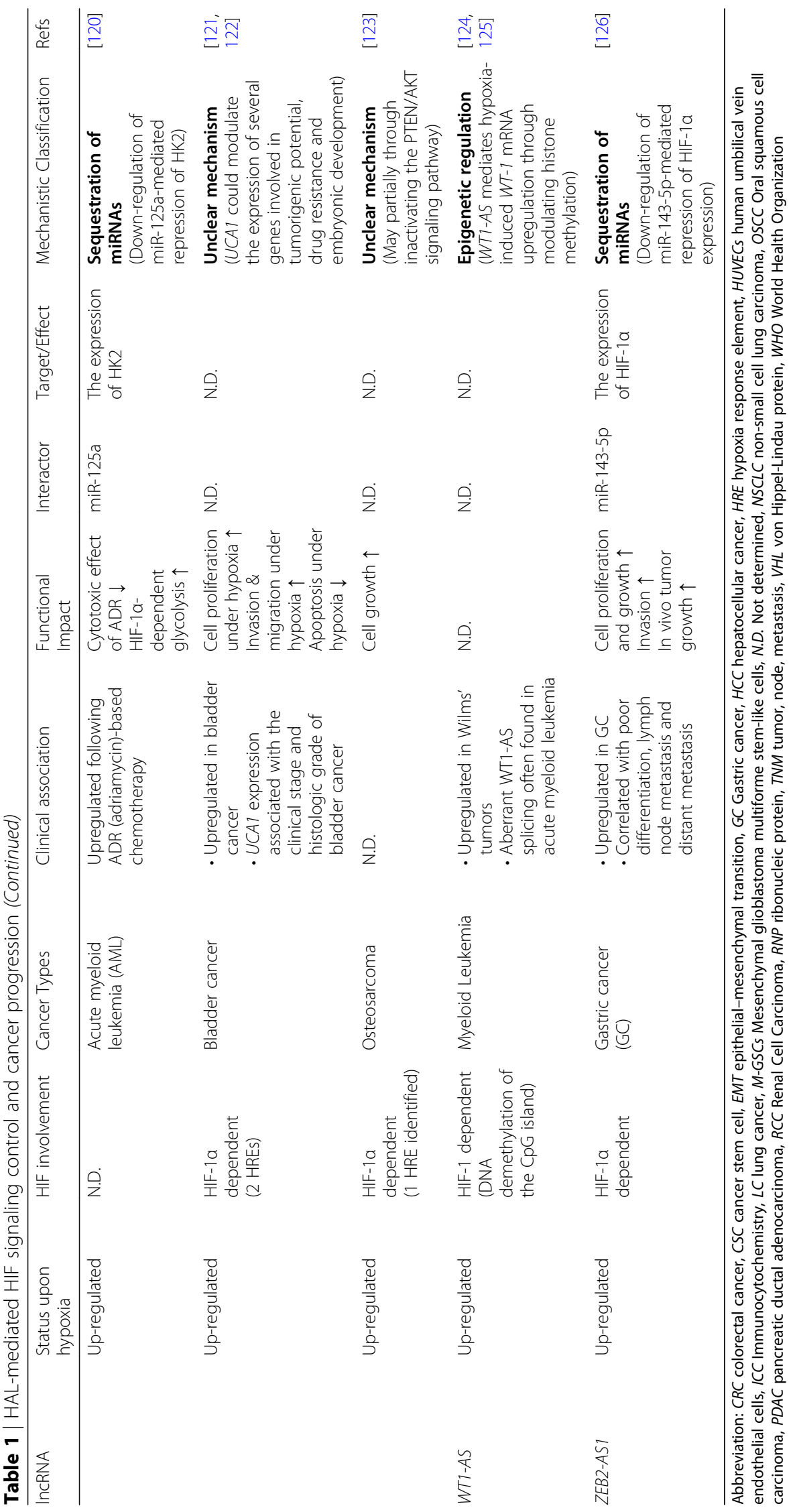


may also have hypoxia-independent functions. For the sake of conciseness, those targets are not included in the table. In addition, some of these lncRNAs can be captured by exosomes and transmitted to tumor microenvironment to exert their functions and further propagate the hypoxic responses (Table 2). Notably, several HALs, such as UCA1, PVT1, H19 and MALAT1, might adapt more than one action mode in different cancer types. In the discussion below, we highlight the selected few HALs to illustrate their mechanisms of actions.

\section{HAL-mediated epigenetic and transcriptional regulation}

A large number of IncRNAs are localized in the nucleus, participating in various biological processes, including chromatin organization, nuclear structure, transcriptional and post-transcriptional regulation of gene expression. With regard to chromatin organization, the pangenomic investigations of RNA-protein interactions have shown that two hypoxia-inducible, oncogenic antisense RNAs ANRIL (also known as CDKN2B antisense RNA 1) and HOTAIR (HOX transcript antisense RNA) $[50,80]$ could interact with different histone-modifying complexes, and have thus been proposed to impact the chromatin modification and transcriptional state [138]. However, whether these two antisense RNAs are involved in modulating gene expression in response to hypoxia via epigenetic modification or chromatin reorganization remains to be characterized. In addition, WT1-AS could mediate hypoxia-induced upregulation of oncogenic transcription factor WT-1 in cis through modulating histone $\mathrm{H} 3 \mathrm{~K} 4$ and $\mathrm{H} 3 \mathrm{~K} 9$ methylation around the transcription start site of WT1 mRNA, contributing to acute myeloid leukemia (AML) progression [124]. Similarly, in gastric cancer, IncRNA-AK058003, which could be profoundly induced by hypoxia, resides upstream of SNCG (synuclein gamma, a synuclein family member, promotes migration, invasion and metastasis) and enhances $S N C G$ expression in cis through demethylation of SNCG promoter CpG islands, thereby driving hypoxia-induced metastasis [90]. In the context of nasopharyngeal carcinoma (NPC), up-regulated PVT1 could serve as a scaffold for a transcriptional activator, the histone acetyltransferase KAT2A, to activate transcription of NF90. NF90, a RNA-binding protein, has been reported to stabilize many target mRNAs, including HIF1A mRNA. Indeed, the upregulated NF90 increased HIF1A mRNA stability and promoted malignant transformation of NPC cells [111]. In addition, in hypoxia-injured pheochromocytoma cells, up-regulated MEG3 (maternally expressed gene 3) could recruit methylation proteins DNMT3a, DNMT3b and MBD1 to facilitate TIMP2 promoter methylation, which in turn inhibited the expression of this cell cycle arrest inducer TIMP2. Moreover, a HIF- $1 \alpha$ negative regulator, OS- -9 , is reported to facilitate HIF- $1 \alpha$ hydroxylation and subsequent proteasomal degradation through tethering the interaction between HIF$1 \alpha$ and prolyl hydroxylases (PHDs) [139]. Interestingly, in pancreatic ductal adenocarcinoma (PDAC), another

Table 2 | HALs identified extracellularly

\begin{tabular}{|c|c|c|c|c|c|}
\hline LncRNA & Extracellular space identified & Cell to Cell Transfer & Functional Impact & Mechanism & Ref \\
\hline $\begin{array}{l}\text { aHIF } \\
\text { (HIFTA-AS2) }\end{array}$ & $\begin{array}{l}\text { Serum } \\
\text { (aHIF level in serum correlates with } \\
\text { its expression in matched } \\
\text { ectopic endometria) }\end{array}$ & $\begin{array}{l}\text { Endometriotic cyst stromal cells } \\
\text { (ECSCs)-derived exosomes to } \\
\text { human umbilical vein endothelial } \\
\text { cells (HUVECs) }\end{array}$ & $\begin{array}{l}\text { Elicits proangiogenic } \\
\text { behavior in HUVECS, thus } \\
\text { facilitating endometriosis } \\
\text { angiogenesis. }\end{array}$ & $\begin{array}{l}\text { Activates VEGF-A, VEGF- } \\
\text { D, and b-FGF in HUVECs }\end{array}$ & [133] \\
\hline CCAT2 & $\begin{array}{l}\text { Exosomes secreted from cultured } \\
\text { glioma cells }\end{array}$ & U87-MG glioma cells to HUVECs & $\begin{array}{l}\text { Promotes HUVEC } \\
\text { angiogenesis and inhibits } \\
\text { apoptosis induced by } \\
\text { hypoxia }\end{array}$ & $\begin{array}{l}\text { Promotes VEGF-A, TGF- } \beta \\
\text { and } B c 12 \text { expression. } \\
\text { Inhibits BAX and caspase } \\
3 \text { expression }\end{array}$ & [134] \\
\hline $\begin{array}{l}\text { HISLA } \\
\text { (LINCO1146) }\end{array}$ & $\begin{array}{l}\text { Extracellular vesicles secreted by } \\
\text { tumor associated fibroblasts (TAMs) }\end{array}$ & TAMs to breast cancer cells & $\begin{array}{l}\text { Enhances aerobic } \\
\text { glycolysis and apoptotic } \\
\text { resistance of cancer cells }\end{array}$ & Stabilizes HIF-1a & [135] \\
\hline PVT1 & $\begin{array}{l}\text { Exosomes secreted from cultured } \\
\text { colon cancer cells. Cancer cells with } \\
\text { more aggressive phenotypes have } \\
\text { more extracellular PVT1 }\end{array}$ & Not determined & $\begin{array}{l}\text { Promotes cell } \\
\text { proliferation and inhibits } \\
\text { apoptosis. }\end{array}$ & & [136] \\
\hline linc- $R O R$ & $\begin{array}{l}\text { Exosomes secreted from cultured } \\
\text { hepatocellular carcinoma cells }\end{array}$ & HCC cancer cells to cancer cells & $\begin{array}{l}\text { Promotes cell survival of } \\
\text { recipient cells }\end{array}$ & $\begin{array}{l}\text { Through a miR-145-HIF- } \\
\text { 1a signaling module to } \\
\text { increase HIF-1a } \\
\text { expression }\end{array}$ & [87] \\
\hline UCA1 & $\begin{array}{l}\text { Exosomes secreted from cultured } \\
\text { bladder cancer cells \& serum }\end{array}$ & $\begin{array}{l}\text { Bladder cancer } 5637 \text { cells with } \\
\text { high expression of UCA1 to } \\
\text { bladder cancer UMUC2 cells with } \\
\text { low expression of UCA1 }\end{array}$ & $\begin{array}{l}\text { Promotes cell } \\
\text { proliferation, migration } \\
\text { and invasion of recipient } \\
\text { cells } \\
\text { Promotes xenograft } \\
\text { growth }\end{array}$ & $\begin{array}{l}\text { Through regulating the } \\
\text { expression of genes } \\
\text { involved in EMT (E-cad, } \\
\text { MMP9, vimentin) }\end{array}$ & [137] \\
\hline
\end{tabular}


lncRNA ENST00000480739 could inhibit HIF-1 $\alpha$ by upregulating OS9 (osteosarcoma amplified-9) expression through enhancing the acetylation of $\mathrm{H} 3 \mathrm{~K} 27$ within OS9 gene promoter [60]. Of note, in PDAC, the level of ENST00000480739 is markedly downregulated, and negatively correlated with lymph node metastasis, in agreement with its negative regulatory role in HIF-1 signaling [60]. As ENST00000480739 resides upstream of the $O S 9$ promoter region, this lncRNA also act in cis to induce $O S 9$ transcription.

Apart from chromatin structure remodeling, a series of HALs could modulate transcription and thereby fine-tune the HIF network. For instance, IncRNA HIF2PUT (HIF-2 $\alpha$ promoter upstream transcript), RERT- $\ln c R N A$ and hypoxia-inducible $B C 005927$ are all found to act in cis to up-regulate neighboring protein-coding genes HIF2A (encodes HIF-2 $\alpha$ ), EGLN2 (encodes prolyl hydroxylase PHD1) and EPHB4 (encodes Ephrin type-B receptor 4, a metastasis-related gene), at the transcriptional level, respectively [51, 76, 116].

Moreover, HALs could directly act on specific transcription factors through physical interactions to modulate their transactivation activities. We recently identified a hypoxia-inducible IncRNA LncHIFCAR (long noncoding HIF-1 $\alpha$ co-activating RNA, also known as MIR31HG) acting as a HIF-1 $\alpha$ co-activator via direct interaction with HIF-1 $\alpha$, thereby enhancing the binding of HIF- $1 \alpha$ and cofactor p300 to the target loci (Fig. 1b). As the abundance of the HIF complex increases, the hypoxia-induced HIF-1 signaling cascade is augmented to further promote subsequent cancer progression [89]. Meanwhile, in pancreatic cancer, HIF-1 $\alpha$-induced lncRNA-MTA2TR (MTA2 transcriptional regulator RNA) transcriptionally upregulates the expression of oncogenic MTA2 (metastasis associated protein 2) by recruiting ATF3 (activating transcription factor 3 ) to the promoter area of MTA2 [102]. Subsequently, MTA2 can enhance the accumulation of HIF- $1 \alpha$ protein via MTA2-mediated HIF- $1 \alpha$ deacetylation and stabilization, which further activates HIF- $1 \alpha$ transcriptional activity, forming feedback loops to augment HIF-1 signaling [102] (Fig. 1c). In addition, through binding to PSF (PTB-associated splicing factor), hypoxia-induced IncRNA MALAT1 released PSF from its downstream proto-oncogene GAGE6 (proto-oncogene G antigen 6) and activated its transcription, thereby promoting proliferation, migration and invasion of lung adenocarcinoma cells $[98,99]$. Given the extraordinary variety of transcriptional regulatory machinery discovered in the cell, it is anticipated that more lncRNAs-mediated regulation on hypoxia-induced transcriptional program will be unraveled in the imminent future.

\section{HAL-mediated post-transcriptional control}

HALs also participate in post-transcriptional regulation including mRNA stability and miRNA-mediated gene silencing.

mRNA stability control Three HALs, IncRNA-LET (Long noncoding RNA Low Expression in Tumor), $D A N C R$ (Differentiation Antagonizing Non-Protein Coding RNA) and HIF1A-AS2 (HIF1A Antisense RNA 2; also known as $a H I F)$, have all been reported to affect HIF1A mRNA stability. IncRNA-LET expression is generally suppressed in various types of tumors, whereas hypoxia-induced HDAC3 (histone deacetylase 3) could repress its expression by reducing the histone acetylation of the $\ln C R N A-L E T$ promoter region [93, 140]. Mechanistically, $\ln R$ RNA-LET is bound to NF90 (nuclear factor 90), which increases NF90 degradation by the proteasome. As RNA binding protein NF90 could stabilize HIF1A mRNA [93, 141], the downregulation of IncRNA$L E T$ upon hypoxia plays a key role in the stabilization of NF90 protein, thereby increasing HIF-1A mRNA stability upon hypoxia and accordingly hypoxia-induced cancer cell invasion [93] (Fig. 1d). Likewise, in nasopharyngeal carcinoma, another oncogenic lncRNA DANCR was upregulated and associated with lymph lode metastasis and poor survival [57]. Through interaction with the NF90/ NF45 complex, DANCR could increase HIF1A mRNA stability, leading to metastasis and disease progression.

In addition, another hypoxia-inducible antisense IncRNA HIF1A-AS2, was shown to be up-regulated in various tumors $[42,43,46,142,143]$ and could differentially regulate HIF- $1 \alpha$ and HIF- $2 \alpha$ expression during long-term hypoxic conditions [43, 47]. Upon acute hypoxia, HIF- $1 \alpha$ and HIF- $2 \alpha$ were similarly induced. Interestingly, during prolonged hypoxia, these two proteins were differentially regulated as HIF- $1 \alpha$ protein level gradually decreased due to a reduction in its mRNA stability, whereas HIF- $2 \alpha$ protein remained upregulated. Meanwhile, long-term hypoxia also induced an increase in $H I F 1 A-A S 2$, whose gene promoter harbors functional HREs. During prolonged hypoxia, HIF1A-AS2 could bind to its sense counterpart, the HIF-1A mRNA 3'UTR, and possibly expose the AU-rich elements in this region, thereby destabilizing $H I F-1 A$ mRNA to convey target gene specificity $[43,47]$. Paradoxically, HIF1A-AS2 was also shown to sequester miR153-3p (see next section) to enhance HIF-1A expression [44]. Thus, the mode of action of HIF1A-AS2 is complex and likely context-dependent.

miRNA sponges A wealth of lncRNAs adapt a wellcharacterized, common mechanism, "ceRNA (competing endogenous RNA)" or "RNA sponges", to repress miRNA-mediated gene silencing. The ceRNAs compete 
for shared miRNAs, sequester these miRNAs and diminish their silencing effect on target mRNAs.

Functional manipulations have demonstrated that several HALs, such as lincRNA-ROR [87], PVT1 [113, 114], HIF1A-AS2 [44], UCA1 [118], HOTAIR [79], FEZF1-AS1 [63], ZEB2-AS1 [126] and $H 19$ [66], could act as a 'ceRNA' to reduce individual specific miRNA-mediated HIF1A mRNA destabilization and thereby restoring HIF$1 \alpha$ levels and consequently promote cancer progression (Table 1). Specifically, in breast cancer stem cells, by absorbing endogenous miRNA let-7 and aborting let-7mediated HIF1A mRNA suppression, hypoxia-induced H19 could stimulate HIF-1 $\alpha$ expression [66] (Fig. 1e). In addition, in glioblastoma, hypoxia-induced H19 upregulation has been shown to confer an aggressive behavior by sequestering miR-181d and nullifying its suppression on an oncogenic EMT-associated factor, $\beta$ catenin [68].

In a similar way, certain HALs could act as a ceRNA to modulate other hypoxia-responsive regulators than HIF-1 $\alpha$. In gastric cancer, GAPLINC (Gastric Adenocarcinoma Associated, Positive CD44 Regulator, Long Intergenic Non-Coding RNA) is a HIF- $1 \alpha$ direct, transcriptional downstream target, and could promote invasive tumor progression [64]. Mechanistically, GAPLINC could serve as a decoy for miR-211-3p to restore the levels of cancer stem cell marker CD44, enhancing tumor progression [65]. Aside from GAPLINC, NORAD [108], UCA1 [119, 120], HOTTIP [82], EIF3J-AS1 [59], MALAT1 [100], FAM201A [62], AGAP2-AS1 [49], LINC01436 [84], NEAT1 [103], NUTF2P3 [109] lncRNAs were shown to function in this way (Table 1). Collectively, in response to hypoxia, the crosstalk among the lncRNA and miRNA transcriptomes build a reciprocal repression feedback network, eliciting concordant shift to transcriptional reprogram. Further exploration of this pertinent co-working group of lncRNAs and miRNAs under hypoxic conditions would help appreciate this emerging additional layer of posttranscriptional regulation governed by HALs.

\section{HAL-mediated control of protein activity, stability and/or higher-order complex formation}

In addition to acting as ceRNAs to modulate gene expression through interaction with miRNAs, HALs have multiple molecular modes to act at the protein level to further modulate gene expression. One of the hypoxiainduced lncRNAs, PVT1 (plasmacytoma variant translocation 1), was implicated in cervical cancer progression, likely through its interaction with a multifunctional shuttling protein, nucleolin [115]. In multiple cancer cell lines, HIF-1-induced lincRNA-p21 provides another example as to how HALs modulate hypoxia response by protein sequestration. Through separate binding to HIF-
$1 \alpha$ and VHL, lincRNA-p21 could increase HIF- $1 \alpha$ accumulation by disruption of the VHL/HIF- $1 \alpha$ interaction and subsequent attenuation of VHL-mediated HIF-1 $\alpha$ ubiquitination and degradation [85] (Fig. 1f). Another HIF-1 $\alpha$ binding lncRNA CASC9 (cancer susceptibility candidate 9) is highly expressed in nasopharyngeal carcinoma (NPC) tissues. CASC9 could interact with and stabilize HIF-1 $\alpha$, promoting the glycolysis and tumorigenesis of NPC cells [53].

Nevertheless, in addition to fine-tuning the activity of one single protein, HALs can also dynamically modulate higher-order protein organizations by serving as scaffolds or molecular decoys. In mesenchymal glioblastoma stemlike cells, through direct binding to two RNA binding proteins, DHX9 (ATP-dependent RNA helicase A) and IGF2BP2 (insulin-like growth factor 2 mRNA-binding protein 2), lncRNA HIF1A-AS2 could facilitate the interaction between this protein complex and their mRNA target HMGA1 (high mobility group AT-hook 1), thereby enhancing HMGA1 expression as well as the downstream molecular response to hypoxic stress [46, 47].

In triple-negative breast cancer (TNBC), LINK-A (long intergenic non-coding RNA for kinase activation) has a critical role in the growth factor-induced HIF- $1 \alpha$ signaling under normoxic conditions [88]. LINK-A is required for the recruitment of BRK (breast tumor kinase) and subsequent enzymatic activation, which is stimulated by HB-EGF (Heparin-binding EGF-like growth factor) signal. HB-EGF mediates the heterodimerization of EGFR (epidermal growth factor receptor) and GPNMB (transmembrane glycoprotein NMB) to form 'EGFR:GPNMB' complex. Due to its direct interaction with BRK and LRRK2 (leucine-rich repeat kinase 2), LINK-A could recruit these two kinases to EGFR:GPNMB heterodimer, thereby inducing their kinase activities, resulting in HIF$1 \alpha$ phosphorylation: BRK-mediated HIF- $1 \alpha$ phosphorylation at $\mathrm{Tyr}^{565}$, a phosphorylation preventing the adjacent Pro ${ }^{564}$ hydroxylation of HIF- $1 \alpha$ and subsequent HIF- $1 \alpha$ degradation under normoxic conditions; and LRRK2-mediated HIF-1 $\alpha$ phosphorylation at $\mathrm{Ser}^{797}$, which facilitates the interaction of HIF- $1 \alpha$ with the transcriptional cofactor p300 [88] (Fig. 1g). In TNBC samples, both LINK-A abundance and HIF-1 signaling activation are correlated with cancer progression and shorter survival, revealing potential therapeutic targets for TNBC [88].

An additional novel function of lncRNAs is their structural role in the assembly of nuclear domains. For instance, MALAT1 (metastasis-associated lung adenocarcinoma transcript 1, also known as NEAT2) and NEAT1 (nuclear enriched abundant transcript 1) are located in two well-characterized nuclear bodies, nuclear speckles and paraspeckles, respectively. Also known as SC35 splicing domains, nuclear speckles are membrane-less 
compartments and their formation involves "phase-separation" mediated by aggregated lncRNAs and proteins. Being an abundant component of the nuclear speckles, MALAT1 associates with numerous splicing factors and other SR (serine/arginine-rich) proteins, and is required for their correct localization to the nuclear speckles, although the overall nuclear speckle assembly is not dependent on the abundance of MALAT1 [144, 145]. So far, the functional involvement of MALAT1 in RNA splicing in response to hypoxia remains to be determined. In contrast, IncRNA NEAT1 is shown to be an essential architectural component of nuclear paraspeckles $[144,145]$. The precise function of paraspeckles remains largely elusive, but proposed to regulate gene expression via the retention of hyper-edited RNA and other multifunctional factors in the nucleus [104]. Given the functional involvement of both MALAT1 and $N E A T 1$ in nuclear structure, further investigation of the extent to which these nuclear structures and their associated transcription reprogramming respond to hypoxia will deepen our understanding of the cellular dynamic response to hypoxia.

\section{HAL-mediated control of hypoxia response via unclear mechanism}

As listed in Table 1, most of the HALs identified with profound impact on tumorigenesis have not yet been examined in mechanistic detail. However, other reports regarding the same lncRNA with functional characterization might reveal clues about their biological roles in response to hypoxia. For instance, lncRNA PCGEM1 was found to be overexpressed in gastric cancer, and could be induced by hypoxia [110]. In gastric cancer cells, PCGEM1 could promote the invasion and metastasis through activating the expression of SNAI1, a key transcription factor of EMT, though the underlying mechanism remains elusive [110]. Notably, in prostate cancer, our group previously reported that the oncogenic PCGEM1 could promote chromatin recruitment of cMyc and enhances its transactivation activity through direct physical interaction [146]. As SNAI1 is a wellcharacterized downstream gene of c-Myc, the possible functional role of the PCGEM1/c-Myc/SNAI1 signaling axis in hypoxia-associated cancer progression warrants further investigation.

In summary, as noted in the above sections, given the relatively large size and the structural flexibility of lncRNAs, it is to be expected that they interact with multiple RNA or protein components and have multifunctions, perhaps in a context-dependent manner. As such, their roles in hypoxia responses and in tumor progression may differ appreciably in different cancer types.
LncRNAs as predictive biomarkers and therapeutic targets for hypoxic tumor

Extracellular vesicles-containing HALs and their biologic effects on tumorigenesis

Extracellular vesicles are effective devices for transporting biomolecules among various cells types [147, 148]. Based on the difference in size and biogenesis, cellderived extracellular vesicles can be broadly divided into two main categories: exosomes (30-100 nm in diameter) and microvesicles. Together with proteins and other non-coding RNAs, emerging evidence has shown that lncRNAs are packaged into exosomes [149, 150], and the abundance of IncRNAs in exosomes correlates with their expression level in the cell of origin [151]. Through exosomal transfer, several IncRNAs are shown to potentiate cell responses to hypoxia between cancer cells [87], as well as between cancer cell and the associated microenvironment [150]. Table 2 summarizes hypoxiaassociated lncRNAs identified extracellularly. For example, linc-ROR was found abundant in tumor cells as well as in exosomes derived from tumor cells [87]. It is increased both in cells or exosomes during hypoxia, and it up-regulates HIF- $1 \alpha$ expression by absorbing miR-145. By co-culture systems, linc-ROR-containing exosomes increase HIF-1a transcription in recipient cells [87]. Hypoxia can shape and fine tune specific macrophage phenotypes in the tumor milieu that are known to promote tumor progression [152]. Chen et al found lncRNA HISLA (also known as LINC01146), secreted by tumorassociated macrophages, stabilized HIF-1 $\alpha$ and enhanced aerobic glycolysis in cancer cells, leading to contagious metabolic reprogramming within tumor regions [150]. PVT1, a lncRNA that often co-amplifies with c-myc and functions as miRNA sponge to upregulate HIF- $1 \alpha$ expression [153, 154], is another example of exosomal transfer between TAMs (tumor associated macrophages) and cancer cells. PVT1 is detected in exosomes derived from colon cancer cells, particularly in more aggressive cells [136]. In granulocytic myeloid-derived suppressor cells (G-MDSCs), PVT1 was up-regulated by HIF-1 $\alpha$ under hypoxia and contributed to immunosuppression, given its depletion reduced the suppression of these cells on T-cells and delayed tumor progression [155]. Other exosomal-transferred IncRNAs that are implicated in cancer cells during hypoxia include UCA1 in bladder cancer for promoting tumor growth and EMT [137], and CCAT2 for glioma's resistance to apoptosis and angiogenesis [134].

The functions of lncRNAs in exosomes for tumor progression await to be explored given a significant level of non-coding RNAs are revealed in exosomes (and elevated upon hypoxia) whereas only a small fraction has been studied [149, 150, 156]. Accordingly, it is conceivable that multiple tumor phenotypes and signaling 
pathways are affected upon exosomal loading. Indeed, by microarray analyses, Mao et al showed hundreds of lncRNAs, together with other transcripts, are changed in endothelial cell recipients of exosomes derived from squamous cancer cells [157]. Importantly, they found exosomes obtained from hypoxic condition facilitate angiogenesis and metastasis better than those obtained from normoxic condition in a xenograft model. Similar effects between normoxic exosomes and hypoxic exosomes on angiogenesis were found in a mouse xenograft model of glioblastoma, with additional effect on accelerating tumor expansion at later stage [158]. The elevation in transcripts by exosomes could result from direct gene transfer, or sequential effects mediated by the transferred genes. By which mechanism IncRNAs are selected to be packaged in the exosomes upon stimuli is not known; nevertheless, these studies revealed exosomes as a means by which hypoxia in the tumor microenvironment facilitates tumor cells to spread and progress.

\section{Diagnostic potential of HALs}

Several HALs with known oncogenic functions have been detected in patient-derived exosomes, including $H 19$ in serum from patients with bladder cancer [159], HOTAIR in urinary exosomes from patients with urothelial bladder cancer [156], UCA1 in serum from bladder cancer patients [137], and HIF1A-AS2 in patients with endometriosis [133]. Future studies aimed at identifying hypoxia-responsive transcripts in extracellular vesicles would surely reveal more players in this aspect. Bearing differential expression patterns between normal and malignant stages and/or tumor size, oncogenic lncRNAs that can be detected extracellularly would potentially serve as non-invasive biomarkers for early detection, prognosis prediction, and disease surveillance. $P C A 3$, up-regulated in $>90 \%$ of men with prostate cancer, is an example of this [160]. A urine-based assay has been approved by the United States Food and Drug Administration (FDA) since 2012 as an alternative diagnostic test for patients undergoing repeat prostate biopsy or with previous negative prostate biopsy.

As described above, there is considerable evidence indicating hypoxia as a progression factor for tumor development [161]. Hypoxia promotes angiogenesis, tumor metastasis, immune evasion and therapy-resistance. The oxygenation status of tumor was reported to influence local tumor response to radiation treatment, as well as overall survival in a variety of tumors [162-164]. Chemotherapeutic drugs, such as Docetaxel and Sorafenib, also tend to be more effective in normoxic conditions $[165,166]$. The hypoxic regions in tumors are infiltrated with cells which promote tumor tolerance (regulatory Tcells, myeloid-derived suppressor cells, and macrophages), while antitumor T-cells are devoid and inhibited by HIF-
$1 \alpha$-mediated accumulation of extracellular adenosine [167-169]. PD-L1 (Programmed death-ligand 1), a ligand expressed by tumor cells or myeloid-derived suppressor cells to suppress T-cell's anti-tumor immunity, is upregulated by and a direct target of HIF- $1 \alpha$ during hypoxia [170]. It has become increasingly apparent that hypoxia in tumors fosters immune suppression and prevents effective immunotherapy. Considering the ill-effects of hypoxia, it is important to detect and to overcome tumor hypoxia even before therapy starts, for the best of patient care.

By far, while there has been a great deal of interest in methodologies to measure hypoxia in patients, an efficient, non-invasive, while sensitive method to detect small regions of hypoxia that frequently occur in the tumors is still lacking [163]. A few metabolic markers (HIF-1 $\alpha$, HIF-2, CA9 and GLUT1) have been used to assess low oxygen tensions by immunohistochemistry [171, 172]; however, the application of them in clinic is limited given that their expressions can be triggered by factors other than hypoxia and that biopsies only represent a small sampling of the tumor. As exosome composition mirrors the hypoxia status of tumors [158], a hypoxia signature may be formulated based on the exosomal hypoxia-responsive transcripts including HALs to evaluate oxygenation in the body for clinical exploitation, once our knowledge is advanced.

\section{Therapeutic potential of HALs (targeting hypoxia in cancer therapy, a IncRNA perspective)}

Several approaches have been proposed to target hypoxia in tumor $[161,163]$. These include drugs that induce cell death selectively in hypoxic cells, e.g. hypoxia-activated prodrugs, or drugs sensitizing hypoxic cells to radiation. Since the adaptive response to hypoxia mainly orients from the transactivation of HIF signaling, some approaches seek to block hypoxia-induced responses by targeting HIFs and the related signaling, or to target pathways that also play pivotal roles in hypoxia adaptation, such as signaling involving mTOR, DNA damage response, and the unfolded protein response. In that regard, HALs that are elevated upon hypoxia and contribute to tumor progression in pre-clinical studies could potentially serve as molecular targets, e.g. PVT, LncHIFCAR, etc. (see Table 1) [41]. By contrast, HALs that are repressed in

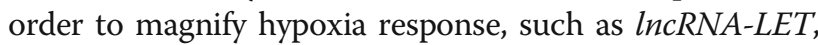
could be induced for therapeutic intervention.

Various strategies have been developed to modulate RNAs. Silencing lncRNAs by small interfering RNAs, antisense oligonucleotides (ASOs), or ribozymes and deoxynucleotides are well demonstrated in pre-clinical studies. Until now, three ASOs and one aptamer therapies have been approved by the FDA for diseases and a handful of others are in clinical trials. The development of short oligonucleotides that fold into three-dimensional structures, 
aptamers, offers a greater specificity as they target specific structure regions to either mediate RNA degradation or disrupt functional interactions between binding partners [173]. Small molecules that bind to lncRNA and hinder its interaction surface have similar advantages. Additionally, peptide nucleic acids (PNA)-based approach against lncRNAs have been described. HOTAIR-targeting PNAs conjugated with $\mathrm{pH}$-low insertion peptide (pHLIP) successfully delivered the anti-lncRNA to the acidic tumor. It blocked the interaction between HOTAIR and EZH2, subsequently inhibited HOTAIR-EZH2 activity and resensitized resistant ovarian tumors to platinum [174].

In any case, an issue all hypoxia-based therapeutics need to consider is the poorly perfused tissue in tumors. In response to their rapid growth, tumor cells secret pro-angiogenic factors such as VEGF to induce vascular formation, yet the constant stimulation leaves tumor vasculature ill-formed and leaky [175]. Simultaneous blockade of HIFs and pro-angiogenic factors has been proposed for targeting tumor hypoxia, in that targeting the angiogenic factors may allow vasculature to mature, resulting more effective blood supply and drug delivery. Another strategy is to relieve oxygen demand by drugs that alleviates oxygen tension in tumors. Papaverine, an FDA-approved drug as a smooth muscle relaxant, was found to inhibit mitochondria complex I and enhance the response to radiotherapy, while well-oxygenated normal tissues were not sensitized [176]. Accordingly, lncRNAs that regulate mitochondria respiration may be considered for targeting tumor hypoxia as an adjuvant treatment.

\section{Conclusion and future perspectives}

Decades of intensive scientific research on hypoxia and HIF biology has greatly contributed to our understanding of oxygen homeostasis. Over the past few years, a substantial increase in our knowledge of the noncoding transcriptomes, while putting on an additional layer of complexity in hypoxia regulation and responses, has advanced our comprehension of hypoxic biology. This review has presented an update of our current insights regarding lncRNAs involved in hypoxia-associated processes, highlighting the diverse mechanisms and functions of hypoxia-associated lncRNAs (HALs). These novel action modes unveil the unanticipated predominance of HALs in the regulation of gene expression under hypoxic conditions and outline the elaborate network among the different types of RNA transcripts, chromatin DNA and protein factors. However, advancement in analytical methodologies and in structural and genomic technologies of RNA are required to open up new important directions for in-depth investigation. For the state-of-the-art methodologies to unveil the functions of IncRNAs, readers are directed to two excellent recent reviews $[177,178]$, as well as those in this special issue.
The role of HIF in hypoxia responses has been the central topic of most investigations. Indeed, HIF has been shown to be a central regulator of the coding and non-coding transcriptome and tightly associated with cancer risk [12, 179-181]. Most HALs, in particular, are highly responsive to hypoxia and HIF and, in turn, participate in the regulation of the protein-coding genome either in cis or in trans to offer multiple routes to HIFmediated gene regulation, implementing both positive and negative feedback loops that either strengthen or repress the hypoxia response. Most notably, the extracellular vesicles-containing HALs could evoke peculiar response to specific cell population, affecting nearby cells and those at a great distance, diversifying the hypoxia response far beyond the previously recognized. The cellular adaptation to hypoxia requires the precisely coordinated regulatory network to cope with the acute, transient and dynamic oxygen deprivation stress in local regions, whereas IncRNAs, with their flexible structure for interaction and quick biogenesis nature, could be uniquely suited to provide rapid, precise and reversible responses to this insult. It is clear that HALs and their downstream targets are shown to confer a series of biological effective responses to hypoxia. Feasibly, this extensive molecular crosstalk between lncRNA and hypoxic signaling cascades may undergo co-evolution to maintain such an exquisite, orchestrated program. Thus, for a comprehensive understanding of hypoxiaassociated tumor biology, it is of relevance to characterize the long non-coding transcriptome involved in hypoxia adaptation.

Given the prominent pathological roles of HALs in hypoxia-associated cancer progression, these RNAs could be exploited as useful indicators to define the cancer intrinsic subtypes to aid in precision medicine. Importantly, HALs are often tissue specific and respond to hypoxia in a cell context dependent manner. As such, they are excellent markers for tissue and tumor hypoxia responses. Compared with other bio-molecules, IncRNAs are ideal biomarkers that provide specificity, stability, sensitivity and easy accessibility [38]. Most notably, cell-free lncRNAs or those packed in extracellular vesicles can be detectable in various body fluids [182]. Hence, the genome-wide annotation of tissue-specific HAL signatures could guide development of promising, non-invasive biomarkers for early diagnosis, prognosis and prediction. Although most lncRNA-targeted treatments are still in their infancy stages, the recent success in RNA-based therapeutics holds promises for future technical innovations. With in-depth characterization of the interplay among hypoxia microenvironment and IncRNA function, more HALs could surely accelerate the design of therapeutics for tumor patients, enabling the targeting of the previously undruggable transcriptome in the near future. 


\section{Supplementary information}

Supplementary information accompanies this paper at https://doi.org/10. 1186/s12929-020-00654-X.

Additional file 1: Table S1. Hypoxia-associated IncRNAs.

\section{Abbreviations}

ASO: Antisense oligonucleotide; bHLH-PAS: Basic helix-loop-helix DNA binding proteins of the PER-ARNT-SIM family; BRK: Breast tumor kinase; ceRNA: competitive endogenous RNA; CRC: Colorectal cancer; CSC: Cancer stem cell; DHX9: ATP-dependent RNA helicase A; EGFR: epidermal growth factor receptor; EMT: Epithelial-mesenchymal transition; FDA: Food and Drug Administration; GC: Gastric cancer; G-MDSCs: Granulocytic myeloid-derived suppressor cells; GPNMB: Transmembrane glycoprotein NMB;

GSC: Glioblastoma stem-like cells; HB-EGF: Heparin-binding EGF; HCC: Hepatocellular cancer; HMGA1: High mobility group AT-hook 1; HAL: Hypoxia-associated IncRNAs; HUVECs: Human umbilical vein endothelial cells; IGF2BP2: Insulin-like growth factor 2 mRNA-binding protein 2; LC: Lung cancer; IncRNA: long non-coding RNA; LRRK2: Leucine-rich repeat kinase 2; M-GSCs: Mesenchymal glioblastoma multiforme stem-like cells; ncRNA: noncoding RNA; N.D.: Not determined; NF90: Nuclear factor 90; NSCLC: Nonsmall cell lung carcinoma; OGT: O-linked N-acetylglucosamine transferase; OS-9: Osteosarcoma amplified-9; OSCC: Oral squamous cell carcinoma; PDAC: Pancreatic ductal adenocarcinoma; PD-L1: Programmed death-ligand 1; pHLIP: pH-low insertion peptide; PNA: Peptide nucleic acids; RCC: Renal Cell Carcinoma; SNCG: Synuclein gamma; TNBC: Triple-negative breast cancer; UTR: Untranslated region; VEGF: Vascular endothelial growth factor; VHL: Von Hippel-Lindau protein

\section{Acknowledgements}

None.

\section{Authors' contributions}

TCK, JWS and HJK wrote the manuscript. All authors read and approved the final manuscript.

\section{Funding}

This work was financially supported by the "TMU Research Center of Cancer Translational Medicine" from The Featured Areas Research Center Program within the framework of the Higher Education Sprout Project by the Ministry of Education (MOE) in Taiwan (to JWS and HJK). It is also supported by grants MOST108-2321-B-010-013-MY2, MOST108-2320-B-038-011 and MOST107-2320-B-038-055-MY3 from Ministry of Science and Technology of Taiwan (to HJK); TMU106-AE1-B52 from Taipei Medical University and MOST108-2320-B-038-009-MY2 from Ministry of Science and Technology of Taiwan (to JWS). TCK was supported by an independent research scholar grant from Ministry of Science and Technology of Taiwan (MOST 105-2321-B400-011-MY3), and is indebted to Ting-Feng Tsai (National Yang-Ming University) for her support after the end of the grant.

\section{Availability of data and materials}

Not Applicable.

\section{Ethics approval and consent to participate}

Not applicable.

\section{Consent for publication}

Not Applicable.

\section{Competing interests}

The authors declare that they have no competing interests.

\section{Author details}

${ }^{1}$ Institute of Molecular and Genomic Medicine, National Health Research Institutes, Zhunan, Miaoli County 35053, Taiwan, ROC. ${ }^{2}$ Graduate Institute of Cancer Biology and Drug Discovery, College of Medical Science and Technology, Taipei Medical University, Taipei 11031, Taiwan, ROC. ${ }^{3}$ Ph.D. Program for Cancer Biology and Drug Discovery, College of Medical Science and Technology, Taipei Medical University, Taipei 11031, Taiwan, ROC. ${ }^{4}$ Department of Biochemistry and Molecular Medicine, Comprehensive
Cancer Center, University of California at Davis, Sacramento, CA 95817, USA. ${ }^{5} \mathrm{TMU}$ Research Center of Cancer Translational Medicine, Taipei Medical University, Taipei 110, Taiwan, ROC. ${ }^{6} \mathrm{Ph} . \mathrm{D}$. Program for Translational Medicine, College of Medical Science and Technology, Taipei Medical University, Taipei 11031, Taiwan, ROC.

Received: 27 February 2020 Accepted: 22 April 2020

Published online: 05 May 2020

\section{References}

1. Semenza GL. Oxygen sensing, hypoxia-inducible factors, and disease pathophysiology. Annu Rev Pathol. 2014;9:47-71.

2. Liu Q, Liu L, Zhao Y, Zhang J, Wang D, Chen J, He Y, Wu J, Zhang Z, Liu Z Hypoxia induces genomic DNA demethylation through the activation of HIF-1alpha and transcriptional upregulation of MAT2A in hepatoma cells. Mol Cancer Ther. 2011;10:1113-23.

3. Jackson AL, Zhou B, Kim WY. HIF, hypoxia and the role of angiogenesis in non-small cell lung cancer. Expert Opin Ther Targets. 2010;14:1047-57.

4. Harrison LR, Micha D, Brandenburg M, Simpson KL, Morrow CJ, Denneny O, Hodgkinson C, Yunus Z, Dempsey C, Roberts D, Blackhall F, Makin G, Dive C. Hypoxic human cancer cells are sensitized to $\mathrm{BH}-3$ mimetic-induced apoptosis via downregulation of the $\mathrm{BCl}-2$ protein $\mathrm{Mcl}-1$. J Clin Invest. 2011; 121:1075-87.

5. Iyer NV, Kotch LE, Agani F, Leung SW, Laughner E, Wenger RH, Gassmann M, Gearhart JD, Lawler AM, Yu AY, Semenza GL. Cellular and developmental control of $\mathrm{O} 2$ homeostasis by hypoxia-inducible factor 1 alpha. Genes Dev. 1998;12:149-62.

6. Wang GL, Jiang BH, Rue EA, Semenza GL. Hypoxia-inducible factor 1 is a basic-helix-loop-helix-PAS heterodimer regulated by cellular $\mathrm{O} 2$ tension. Proc Natl Acad Sci U S A. 1995:92:5510-4.

7. Makino Y, Kanopka A, Wilson WJ, Tanaka H, Poellinger L. Inhibitory PAS domain protein (IPAS) is a hypoxia-inducible splicing variant of the hypoxiainducible factor-3alpha locus. J Biol Chem. 2002;277:32405-8.

8. Maynard MA, Evans AJ, Hosomi T, Hara S, Jewett MA, Ohh M. Human HIF3alpha4 is a dominant-negative regulator of HIF-1 and is down-regulated in renal cell carcinoma. FASEB J. 2005;19:1396-406.

9. Semenza GL. Defining the role of hypoxia-inducible factor 1 in cancer biology and therapeutics. Oncogene. 2010;29:625-34.

10. Kaelin WG Jr, Ratcliffe PJ. Oxygen sensing by metazoans: the central role of the HIF hydroxylase pathway. Mol Cell. 2008;30:393-402.

11. Keith B, Simon MC. Hypoxia-inducible factors, stem cells, and cancer. Cell. 2007;129:465-72.

12. Choudhry H, Schodel J, Oikonomopoulos S, Camps C, Grampp S, Harris AL, Ratcliffe PJ, Ragoussis J, Mole DR. Extensive regulation of the non-coding transcriptome by hypoxia: role of HIF in releasing paused RNApol2. EMBO Rep. 2014;15:70-6.

13. Gee HE, Ivan C, Calin GA, Ivan M. HypoxamiRs and cancer: from biology to targeted therapy. Antioxid Redox Signal. 2014;21:1220-38.

14. Chang YN, Zhang K, Hu ZM, Qi HX, Shi ZM, Han XH, Han YW, Hong W. Hypoxia-regulated IncRNAs in cancer. Gene. 2016;575:1-8.

15. Choudhry H, Harris AL, Mclntyre A. The tumour hypoxia induced noncoding transcriptome. Mol Aspects Med. 2016;47-48:35-53.

16. Dong J, Xu J, Wang $X$, Jin B. Influence of the interaction between long noncoding RNAs and hypoxia on tumorigenesis. Tumour Biol. 2016;37: 1379-85.

17. Rinn JL, Chang HY. Genome regulation by long noncoding RNAs. Annu Rev Biochem. 2012;81:145-66.

18. Kung JT, Colognori D, Lee JT. Long noncoding RNAs: past, present, and future. Genetics. 2013;193:651-69.

19. Baker M. Long noncoding RNAs: the search for function. Nat Methods. 2011; 8:379-83.

20. Moran VA, Perera RJ, Khalil AM. Emerging functional and mechanistic paradigms of mammalian long non-coding RNAs. Nucleic Acids Res. 2012; 40:6391-400.

21. Wilusz JE, Sunwoo H, Spector DL. Long noncoding RNAs: functional surprises from the RNA world. Genes Dev. 2009;23:1494-504.

22. Lee JT. Epigenetic regulation by long noncoding RNAs. Science. 2012;338: 1435-9.

23. Yang L, Froberg JE, Lee JT. Long noncoding RNAs: fresh perspectives into the RNA world. Trends Biochem Sci. 2014;39:35-43. 
24. Wang KC, Chang HY. Molecular mechanisms of long noncoding RNAs. Mo Cell. 2011;43:904-14.

25. Bohmdorfer G, Wierzbicki AT. Control of chromatin structure by long noncoding RNA. Trends Cell Biol. 2015;25:623-32.

26. Bonasio R, Shiekhattar R. Regulation of transcription by long noncoding RNAs. Annu Rev Genet. 2014:48:433-55.

27. Schmitt AM, Chang HY. Long noncoding RNAs in Cancer pathways. Cancer Cell. 2016;29:452-63.

28. Geisler S, Coller J. RNA in unexpected places: long non-coding RNA functions in diverse cellular contexts. Nat Rev Mol Cell Biol. 2013;14:699712.

29. Batista PJ, Chang HY. Long noncoding RNAs: cellular address codes in development and disease. Cell. 2013;152:1298-307.

30. Gong C, Maquat LE. IncRNAs transactivate STAU1-mediated mRNA decay by duplexing with 3' UTRs via Alu elements. Nature. 2011;470:284-8.

31. Clemson CM, Hutchinson JN, Sara SA, Ensminger AW, Fox AH, Chess A, Lawrence JB. An architectural role for a nuclear noncoding RNA: NEAT1 RNA is essential for the structure of paraspeckles. Mol Cell. 2009;33:717-26.

32. Shevtsov SP, Dundr M. Nucleation of nuclear bodies by RNA. Nat Cell Biol. 2011;13:167-73.

33. Hung T, Chang HY. Long noncoding RNA in genome regulation: prospects and mechanisms. RNA Biol. 2010;7:582-5.

34. Wapinski $\mathrm{O}$, Chang HY. Long noncoding RNAs and human disease. Trends Cell Biol. 2011;21:354-61.

35. Gibb EA, Brown CJ, Lam WL. The functional role of long non-coding RNA in human carcinomas. Mol Cancer. 2011;10:38.

36. Gutschner T, Diederichs S. The hallmarks of cancer: a long non-coding RNA point of view. RNA Biol. 2012;9:703-19.

37. Spizzo R, Almeida MI, Colombatti A, Calin GA. Long non-coding RNAs and cancer: a new frontier of translational research? Oncogene. 2012;31:4577-87.

38. Huarte M. The emerging role of IncRNAs in cancer. Nat Med. 2015:21:125361.

39. Qiu MT, Hu JW, Yin R, Xu L. Long noncoding RNA: an emerging paradigm of cancer research. Tumour Biol. 2013;34:613-20.

40. Choudhry H, Harris AL. Advances in hypoxia-inducible factor biology. Cell Metab. 2018;27:281-98.

41. Shih JW, Kung HJ. Long non-coding RNA and tumor hypoxia: new players ushered toward an old arena. J Biomed Sci. 2017;24:53.

42. Thrash-Bingham CA, Tartof KD. aHIF: a natural antisense transcript overexpressed in human renal cancer and during hypoxia. J Natl Cancer Inst. 1999;91:143-51.

43. Rossignol F, Vache C, Clottes E. Natural antisense transcripts of hypoxiainducible factor 1alpha are detected in different normal and tumour human tissues. Gene. 2002;299:135-40.

44. Li L, Wang M, Mei Z, Cao W, Yang Y, Wang Y, Wen A. IncRNAs HIF1A-AS2 facilitates the up-regulation of HIF-1alpha by sponging to miR-153-3p, whereby promoting angiogenesis in HUVECs in hypoxia. Biomed Pharmacother. 2017;96:165-72.

45. Chen X, Liu M, Meng F, Sun B, Jin X, Jia C. The long noncoding RNA HIF1AAS2 facilitates cisplatin resistance in bladder cancer. J Cell Biochem. 2019; 120:243-52.

46. Mineo M, Ricklefs F, Rooj AK, Lyons SM, Ivanov P, Ansari KI, Nakano I, Chiocca EA, Godlewski J, Bronisz A. The long non-coding RNA HIF1A-AS2 facilitates the maintenance of mesenchymal glioblastoma stem-like cells in hypoxic niches. Cell Rep. 2016;15:2500-9.

47. Uchida T, Rossignol F, Matthay MA, Mounier R, Couette S, Clottes E, Clerici C. Prolonged hypoxia differentially regulates hypoxia-inducible factor (HIF)1alpha and HIF-2alpha expression in lung epithelial cells: implication of natural antisense HIF-1alpha. J Biol Chem. 2004;279:14871-8.

48. Qiu JJ, Lin XJ, Zheng TT, Tang XY, Hua KQ. Natural antisense transcript of hypoxia-inducible factor 1 regulates hypoxic cell apoptosis in epithelial ovarian cancer. Onco Targets Ther. 2018;11:9101-10.

49. Liu Z, Wang Y, Wang L, Yao B, Sun L, Liu R, Chen T, Niu Y, Tu K, Liu Q. Long non-coding RNA AGAP2-AS1, functioning AS a competitive endogenous RNA, upregulates ANXA11 expression by sponging miR-16-5p and promotes proliferation and metastasis in hepatocellular carcinoma. J Exp Clin Cancer Res. 2019;38:194.

50. Wei X, Wang C, Ma C, Sun W, Li H, Cai Z. Long noncoding RNA ANRIL is activated by hypoxia-inducible factor-1alpha and promotes osteosarcoma cell invasion and suppresses cell apoptosis upon hypoxia. Cancer Cell Int. 2016;16:73.
51. Liu X, Wang Y, Sun L, Min J, Liu J, Chen D, Zhang $H$, Zhang $H$, Zhang $H$, Zhou Y, Liu L. Long noncoding RNA BC005927 upregulates EPHB4 and promotes gastric cancer metastasis under hypoxia. Cancer Sci. 2018;109: 988-1000.

52. Deng SJ, Chen HY, Ye Z, Deng SC, Zhu S, Zeng Z, He C, Liu ML, Huang K, Zhong JX, Xu FY, Li Q, Liu Y, Wang CY, Zhao G. Hypoxia-induced LncRNABX111 promotes metastasis and progression of pancreatic cancer through regulating ZEB1 transcription. Oncogene. 2018;37:5811-28.

53. Su X, Li G, Liu W. The long noncoding RNA Cancer susceptibility candidate 9 promotes nasopharyngeal carcinogenesis via stabilizing HIF1alpha. DNA Cell Biol. 2017:36:394-400.

54. Liu M, Zhong J, Zeng Z, Huang K, Ye Z, Deng S, Chen H, Xu F, Li Q, Zhao G. Hypoxia-induced feedback of HIF-1alpha and IncRNA-CF129 contributes to pancreatic cancer progression through stabilization of p53 protein. Theranostics. 2019;9:4795-810.

55. Zhang W, Yuan W, Song J, Wang S, Gu X. LncRNA CPS1-IT1 suppresses EMT and metastasis of colorectal cancer by inhibiting hypoxia-induced autophagy through inactivation of HIF-1alpha. Biochimie. 2018;144:21-7.

56. Zhang W, Wang J, Chai R, Zhong G, Zhang C, Cao W, Yan L, Zhang X, Xu Z. Hypoxia-regulated IncRNA CRPAT4 promotes cell migration via regulating AVL9 in clear cell renal cell carcinomas. Onco Targets Ther. 2018;11:4537-45.

57. Wen X, Liu X, Mao YP, Yang XJ, Wang YQ, Zhang PP, Lei Y, Hong XH, He QM, Ma J, Liu N, Li YQ. Long non-coding RNA DANCR stabilizes HIF-1alpha and promotes metastasis by interacting with NF90/NF45 complex in nasopharyngeal carcinoma. Theranostics. 2018;8:5676-89.

58. Tong J, Xu X, Zhang Z, Ma C, Xiang R, Liu J, Xu W, Wu C, Li J, Zhan F, Wu Y, Yan H. Hypoxia-induced long non-coding RNA DARS-AS1 regulates RBM39 stability to promote myeloma malignancy. Haematologica. 2019;104:218289.

59. Yang X, Yao B, Niu Y, Chen T, Mo H, Wang L, Guo C, Yao D. Hypoxiainduced IncRNA EIF3J-AS1 accelerates hepatocellular carcinoma progression via targeting miR-122-5p/CTNND2 axis. Biochem Biophys Res Commun. 2019:518:239-45.

60. Sun YW, Chen YF, Li J, Huo YM, Liu DJ, Hua R, Zhang JF, Liu W, Yang JY, Fu XL, Yan T, Hong J, Cao H. A novel long non-coding RNA ENST00000480739 suppresses tumour cell invasion by regulating OS-9 and HIF-1alpha in pancreatic ductal adenocarcinoma. Br J Cancer. 2014;111:2131-41.

61. Zhao R, Sun F, Bei X, Wang X, Zhu Y, Jiang C, Zhao F, Han B, Xia S. Upregulation of the long non-coding RNA FALEC promotes proliferation and migration of prostate cancer cell lines and predicts prognosis of PCa patients. Prostate. 2017;77:1107-17.

62. Liu AM, Zhu Y, Huang ZW, Lei L, Fu SZ, Chen Y. Long noncoding RNA FAM201A involves in radioresistance of non-small-cell lung cancer by enhancing EGFR expression via miR-370. Eur Rev Med Pharmacol Sci. 2019; 23:5802-14.

63. Ou ZL, Zhang M, Ji LD, Luo Z, Han T, Lu YB, Li YX. Long noncoding RNA FEZF1-AS1 predicts poor prognosis and modulates pancreatic cancer cell proliferation and invasion through miR-142/HIF-1alpha and miR-133a/EGFR upon hypoxia/normoxia. J Cell Physiol. 2019;234:15407-19.

64. Liu L, Zhao X, Zou H, Bai R, Yang K, Tian Z. Hypoxia promotes gastric Cancer malignancy partly through the HIF-1alpha dependent transcriptional activation of the long non-coding RNA GAPLINC. Front Physiol. 2016;7:420.

65. Hu Y, Wang J, Qian J, Kong X, Tang J, Wang Y, Chen H, Hong J, Zou W, Chen $Y, X U$ J, Fang JY. Long noncoding RNA GAPLINC regulates CD44dependent cell invasiveness and associates with poor prognosis of gastric cancer. Cancer Res. 2014;74:6890-902.

66. Peng F, Wang JH, Fan WJ, Meng YT, Li MM, Li TT, Cui B, Wang HF, Zhao Y, An F, Guo T, Liu XF, Zhang L, Lv L, Lv DK, Xu LZ, Xie JJ, Lin WX, Lam EW, Xu J, Liu Q. Glycolysis gatekeeper PDK1 reprograms breast cancer stem cells under hypoxia. Oncogene. 2018;37:1062-74.

67. Corrado C, Costa V, Giavaresi G, Calabrese A, Conigliaro A, Alessandro R. Long non coding RNA H19: a new player in hypoxia-induced multiple myeloma cell dissemination. Int J Mol Sci. 2019;20:801.

68. Wu W, Hu Q, Nie E, Yu T, Wu Y, Zhi T, Jiang K, Shen F, Wang Y, Zhang J, You Y. Hypoxia induces $\mathrm{H} 19$ expression through direct and indirect Hif-1alpha activity, promoting oncogenic effects in glioblastoma. Sci Rep. 2017;7:45029.

69. Matouk IJ, DeGroot N, Mezan S, Ayesh S, Abu-lail R, Hochberg A, Galun E. The H19 non-coding RNA is essential for human tumor growth. PLoS One. 2007;2:e845.

70. Matouk IJ, Mezan S, Mizrahi A, Ohana P, Abu-Lail R, Fellig Y, Degroot N, Galun E, Hochberg A. The oncofetal H19 RNA connection: hypoxia, p53 and cancer. Biochim Biophys Acta. 2010;1803:443-51. 
71. Voellenkle C, Garcia-Manteiga JM, Pedrotti S, Perfetti A, De Toma I, Da Silva D, Maimone B, Greco S, Fasanaro P, Creo P, Zaccagnini G, Gaetano C, Martelli F. Implication of long noncoding RNAs in the endothelial cell response to hypoxia revealed by RNA-sequencing. Sci Rep. 2016;6:24141.

72. Bacci L, Aiello A, Ripoli C, Loria R, Pugliese D, Pierconti F, Rotili D, Strigari L, Pinto F, Bassi PF, Mai A, Grassi C, Pontecorvi A, Falcioni R, Farsetti A, Nanni S. H19-dependent transcriptional regulation of beta3 and beta4 Integrins upon estrogen and hypoxia favors metastatic potential in prostate Cancer. Int J Mol Sci. 2019;20:4012.

73. Matouk IJ, Raveh E, Abu-lail R, Mezan S, Gilon M, Gershtain E, Birman T, Gallula J, Schneider T, Barkali M, Richler C, Fellig Y, Sorin V, Hubert A, Hochberg A, Czerniak A. Oncofetal H19 RNA promotes tumor metastasis. Biochim Biophys Acta. 2014;1843:1414-26.

74. Zheng ZH, Wu DM, Fan SH, Zhang ZF, Chen GQ, Lu J. Upregulation of miR675-5p induced by IncRNA H19 was associated with tumor progression and development by targeting tumor suppressor p53 in non-small cell lung cancer. J Cell Biochem. 2019;120:18724-35.

75. Zhu G, Wang S, Chen J, Wang Z, Liang X, Wang X, Jiang J, Lang J, Li L. Long noncoding RNA HAS2-AS1 mediates hypoxia-induced invasiveness of oral squamous cell carcinoma. Mol Carcinog. 2017;56:2210-22.

76. Wang Y, Yao J, Meng H, Yu Z, Wang Z, Yuan X, Chen H, Wang A. A novel long non-coding RNA, hypoxia-inducible factor-2alpha promoter upstream transcript, functions as an inhibitor of osteosarcoma stem cells in vitro. Mol Med Rep. 2015;11:2534-40.

77. Zhao D, Wang S, Chu X, Han D. LncRNA HIF2PUT inhibited osteosarcoma stem cells proliferation, migration and invasion by regulating HIF2 expression. Artif Cells Nanomed Biotechnol. 2019;47:1342-8.

78. Ferdin J, Nishida N, Wu X, Nicoloso MS, Shah MY, Devlin C, Ling H, Shimizu M, Kumar K, Cortez MA, Ferracin M, Bi Y, Yang D, Czerniak B, Zhang W, Schmittgen TD, Voorhoeve MP, Reginato MJ, Negrini M, Davuluri RV, Kunej T, Ivan M, Calin GA. HINCUTs in cancer: hypoxia-induced noncoding ultraconserved transcripts. Cell Death Differ. 2013;20:1675-87.

79. Hong Q, Li O, Zheng W, Xiao WZ, Zhang L, Wu D, Cai GY, He JC, Chen XM. LncRNA HOTAIR regulates HIF-1alpha/AXL signaling through inhibition of miR-217 in renal cell carcinoma. Cell Death Dis. 2017;8:e2772.

80. Zhou C, Ye L, Jiang C, Bai J, Chi Y, Zhang H. Long noncoding RNA HOTAIR a hypoxia-inducible factor-1alpha activated driver of malignancy, enhances hypoxic cancer cell proliferation, migration, and invasion in non-small cell lung cancer. Tumour Biol. 2015;36:9179-88.

81. Liu XH, Liu ZL, Sun M, Liu J, Wang ZX, De W. The long non-coding RNA HOTAIR indicates a poor prognosis and promotes metastasis in non-small cell lung cancer. BMC Cancer. 2013;13:464

82. Zhang S, Wang W, Liu G, Xie S, Li Q, Li Y, Lin Z. Long non-coding RNA HOTTIP promotes hypoxia-induced epithelial-mesenchymal transition of malignant glioma by regulating the miR-101/ZEB1 axis. Biomed Pharmacother. 2017;95:711-20.

83. Xiang S, Gu H, Jin L, Thorne RF, Zhang XD, Wu M. LncRNA IDH1-AS1 links the functions of c-Myc and HIF1alpha via IDH1 to regulate the Warburg effect. Proc Natl Acad Sci U S A. 2018;115:E1465-E74.

84. Yuan S, Xiang Y, Wang G, Zhou M, Meng G, Liu Q, Hu Z, Li C, Xie W, Wu N, Wu L, Cai T, Ma X, Zhang Y, Yu Z, Bai L, Li Y. Hypoxia-sensitive LINC01436 is regulated by E2F6 and acts as an oncogene by targeting miR-30a-3p in non-small cell lung cancer. Mol Oncol. 2019;13:840-56.

85. Yang F, Zhang H, Mei Y, Wu M. Reciprocal regulation of HIF-1alpha and lincRNA-p21 modulates the Warburg effect. Mol Cell. 2014;53:88-100.

86. Shen $Y$, Liu Y, Sun T, Yang W. LincRNA-p21 knockdown enhances radiosensitivity of hypoxic tumor cells by reducing autophagy through HIF-1/Akt/mTOR/P70S6K pathway. Exp Cell Res. 2017;358: 188-98.

87. Takahashi K, Yan IK, Haga H, Patel T. Modulation of hypoxia-signaling pathways by extracellular linc-RoR. J Cell Sci. 2014;127:1585-94.

88. Lin A, Li C, Xing Z, Hu Q, Liang K, Han L, Wang C, Hawke DH, Wang S, Zhang Y, Wei Y, Ma G, Park PK, Zhou J, Zhou Y, Hu Z, Zhou Y, Marks JR, Liang H, Hung MC, Lin C, Yang L. The LINK-A IncRNA activates normoxic HIF1alpha signalling in triple-negative breast cancer. Nat Cell Biol. 2016;18:213-24.

89. Shih JW, Chiang WF, Wu ATH, Wu MH, Wang LY, Yu YL, Hung YW, Wang WC, Chu CY, Hung CL, Changou CA, Yen Y, Kung HJ. Long noncoding RNA LncHIFCAR/MIR31HG is a HIF-1alpha co-activator driving oral cancer progression. Nat Commun. 2017:8:15874.

90. Wang $Y$, Liu $X$, Zhang $H$, Sun L, Zhou $Y$, Jin H, Zhang $H$, Zhang $H$, Liu J, Guo H, Nie Y, Wu K, Fan D, Zhang H, Liu L. Hypoxia-inducible IncRNA-AK058003 promotes gastric cancer metastasis by targeting gamma-synuclein. Neoplasia. 2014;16:1094-106.

91. Gomez-Maldonado L, Tiana M, Roche O, Prado-Cabrero A, Jensen L, Fernandez-Barral A, Guijarro-Munoz I, Favaro E, Moreno-Bueno G, Sanz L, Aragones J, Harris A, Volpert O, Jimenez B, del Peso L. EFNA3 long noncoding RNAs induced by hypoxia promote metastatic dissemination. Oncogene. 2015;34:2609-20.

92. Garcia-Venzor A, Mandujano-Tinoco EA, Lizarraga F, Zampedri C, Krotzsch E, Salgado RM, Davila-Borja VM, Encarnacion-Guevara S, Melendez-Zajgla J, Maldonado V. Microenvironment-regulated IncRNA-HAL is able to promote stemness in breast cancer cells. Biochim Biophys Acta Mol Cell Res. 2019; 1866:118523.

93. Yang F, Huo XS, Yuan SX, Zhang L, Zhou WP, Wang F, Sun SH. Repression of the long noncoding RNA-LET by histone deacetylase 3 contributes to hypoxia-mediated metastasis. Mol Cell. 2013;49:1083-96.

94. Zhai W, Sun Y, Jiang M, Wang M, Gasiewicz TA, Zheng J, Chang C. Differential regulation of LnCRNA-SARCC suppresses VHL-mutant RCC cell proliferation yet promotes $\mathrm{VHL}$-normal RCC cell proliferation via modulating androgen receptor/HIF-2alpha/C-MYC axis under hypoxia. Oncogene. 2016; 35:4866-80

95. Gao X, Guo X, Xue H, Qiu W, Guo X, Zhang J, Qian M, Li T, Liu Q, Shen J, Deng L, Li G. IncTCF7 is a negative prognostic factor, and knockdown of IncTCF7 inhibits migration, proliferation and tumorigenicity in glioma. Sci Rep. 2017;7:17456

96. Luo F, Sun B, Li H, Xu Y, Liu Y, Liu X, Lu L, Li J, Wang Q, Wei S, Shi L, Lu X, Liu Q, Zhang A. A MALAT1/HIF-2alpha feedback loop contributes to arsenite carcinogenesis. Oncotarget. 2016;7:5769-87.

97. Luo F, Liu X, Ling M, Lu L, Shi L, Lu X, Li J, Zhang A, Liu Q. The IncRNA MALAT1, acting through HIF-1alpha stabilization, enhances arsenite-induced glycolysis in human hepatic L-02 cells. Biochim Biophys Acta. 1862;2016: 1685-95.

98. Hu L, Tang J, Huang X, Zhang T, Feng X. Hypoxia exposure upregulates MALAT-1 and regulates the transcriptional activity of PTB-associated splicing factor in A549 lung adenocarcinoma cells. Oncol Lett. 2018;16:294-300.

99. Li L, Feng T, Lian Y, Zhang G, Garen A, Song X. Role of human noncoding RNAs in the control of tumorigenesis. Proc Natl Acad Sci U S A. 2009;106: 12956-61.

100. Zhao ZB, Chen F, Bai XF. Long noncoding RNA MALAT1 regulates hepatocellular carcinoma growth under hypoxia via sponging MicroRNA200a. Yonsei Med J. 2019;60:727-34.

101. Zheng $X Y$, Lei BX, Lin $Y Y$, Sui MH, Zhang ML, Zhuang ZQ, Dong JT, Jin DM, Yan TB. Long noncoding RNA MEG3 silencing protects against hypoxiainduced pheochromocytoma-12 cell injury through inhibition of TIMP2 promoter methylation. J Cell Physiol. 2020;235:1649-62.

102. Zeng Z, Xu FY, Zheng H, Cheng P, Chen QY, Ye Z, Zhong JX, Deng SJ, Liu ML, Huang K, Li Q, Li W, Hu YH, Wang F, Wang CY, Zhao G. LncRNAMTA2TR functions as a promoter in pancreatic cancer via driving deacetylation-dependent accumulation of HIF-1alpha. Theranostics. 2019;9: 5298-314.

103. Kong X, Zhao Y, Li X, Tao Z, Hou M, Ma H. Overexpression of HIF-2alphadependent NEAT1 promotes the progression of non-small cell lung Cancer through miR-101-3p/SOX9/Wnt/beta-catenin signal pathway. Cell Physiol Biochem. 2019;52:368-81.

104. Choudhry H, Mole DR. Hypoxic regulation of the noncoding genome and NEAT1. Brief Funct Genomics. 2016;15:174-85.

105. Choudhry H, Albukhari A, Morotti M, Haider S, Moralli D, Smythies J, Schodel J, Green CM, Camps C, Buffa F, Ratcliffe P, Ragoussis J, Harris AL, Mole DR. Tumor hypoxia induces nuclear paraspeckle formation through HIF-2alpha dependent transcriptional activation of NEAT1 leading to cancer cell survival. Oncogene. 2015;34:4482-90.

106. Lelli A, Nolan KA, Santambrogio S, Goncalves AF, Schonenberger MJ, Guinot A, Frew IJ, Marti HH, Hoogewijs D, Wenger $\mathrm{RH}$. Induction of long noncoding RNA MALAT1 in hypoxic mice. Hypoxia (Auckl). 2015;3:45-52.

107. Lin HC, Yeh CC, Chao LY, Tsai MH, Chen HH, Chuang EY, Lai LC. The hypoxiaresponsive IncRNA NDRG-OT1 promotes NDRG1 degradation via ubiquitinmediated proteolysis in breast cancer cells. Oncotarget. 2018;9:10470-82.

108. Li H, Wang X, Wen C, Huo Z, Wang W, Zhan Q, Cheng D, Chen H, Deng $X$, Peng $C$, Shen $B$. Long noncoding RNA NORAD, a novel competing endogenous RNA, enhances the hypoxia-induced epithelialmesenchymal transition to promote metastasis in pancreatic cancer. Mol Cancer. 2017;16:169. 
109. Li X, Deng SJ, Zhu S, Jin Y, Cui SP, Chen JY, Xiang C, Li QY, He C, Zhao SF, Chen HY, Niu Y, Liu Y, Deng SC, Wang CY, Zhao G. Hypoxia-induced InCRNA-NUTF2P3-001 contributes to tumorigenesis of pancreatic cancer by derepressing the miR-3923/KRAS pathway. Oncotarget. 2016;7:6000-14.

110. Zhang J, Jin HY, Wu Y, Zheng ZC, Guo S, Wang Y, Yang D, Meng XY, Xu X, Zhao $Y$. Hypoxia-induced LncRNA PCGEM1 promotes invasion and metastasis of gastric cancer through regulating SNAI1. Clin Transl Oncol. 2019;21:1142-51.

111. Wang Y, Chen W, Lian J, Zhang H, Yu B, Zhang M, Wei F, Wu J, Jiang J, Jia Y, Mo F, Zhang S, Liang X, Mou X, Tang J. The IncRNA PVT1 regulates nasopharyngeal carcinoma cell proliferation via activating the KAT2A acetyltransferase and stabilizing HIF-1alpha. Cell Death Differ. 2020;27:695-710.

112. Xu Y, Luo X, He W, Chen G, Li Y, Li W, Wang X, Lai Y, Ye Y. Long noncoding RNA PVT1/miR-150/ HIG2 Axis regulates the proliferation, invasion and the balance of Iron metabolism of hepatocellular carcinoma. Cell Physiol Biochem. 2018;49:1403-19.

113. Huang T, Liu HW, Chen JQ, Wang SH, Hao LQ, Liu M, Wang B. The long noncoding RNA PVT1 functions as a competing endogenous RNA by sponging miR-186 in gastric cancer. Biomed Pharmacother. 2017;88:302-8.

114. Wang C, Han C, Zhang Y, Liu F. LncRNA PVT1 regulate expression of HIF1alpha via functioning as ceRNA for miR199a5p in nonsmall cell lung cancer under hypoxia. Mol Med Rep. 2018;17:1105-10.

115. Iden M, Fye S, Li K, Chowdhury T, Ramchandran R, Rader JS. The IncRNA PVT1 contributes to the cervical Cancer phenotype and associates with poor patient prognosis. PLoS One. 2016;11:e0156274.

116. Zhu Z, Gao X, He Y, Zhao H, Yu Q, Jiang D, Zhang P, Ma X, Huang H, Dong D, Wan J, Gu Z, Jiang X, Yu L, Gao Y. An insertion/deletion polymorphism within RERT-IncRNA modulates hepatocellular carcinoma risk. Cancer Res. 2012;72:6163-72.

117. Lin J, Cao S, Wang Y, Hu Y, Liu H, Li J, Chen J, Li P, Liu J, Wang Q, Zheng L. Long non-coding RNA UBE2CP3 enhances HCC cell secretion of VEGFA and promotes angiogenesis by activating ERK1/2/HIF-1alpha/NEGFA signalling in hepatocellular carcinoma. J Exp Clin Cancer Res. 2018;37:113.

118. Li X, Wu Y, Liu A, Tang X. Long non-coding RNA UCA1 enhances tamoxifen resistance in breast cancer cells through a miR-18a-HIF1alpha feedback regulatory loop. Tumour Biol. 2016;37:14733-43.

119. Yang Z, Shi X, Li C, Wang X, Hou K, Li Z, Zhang X, Fan Y, Qu X, Che X, Liu Y. Long non-coding RNA UCA1 upregulation promotes the migration of hypoxia-resistant gastric cancer cells through the miR-7-5p/EGFR axis. Exp Cell Res. 2018;368:194-201.

120. Zhang Y, Liu Y, Xu X. Knockdown of LncRNA-UCA1 suppresses chemoresistance of pediatric AML by inhibiting glycolysis through the microRNA-125a/hexokinase 2 pathway. J Cell Biochem. 2018;1 19:6296-308.

121. Xue M, Li X, Li Z, Chen W. Urothelial carcinoma associated 1 is a hypoxiainducible factor-1alpha-targeted long noncoding RNA that enhances hypoxic bladder cancer cell proliferation, migration, and invasion. Tumour Biol. 2014:35:6901-12.

122. Wang F, Li X, Xie X, Zhao L, Chen W. UCA1, a non-protein-coding RNA upregulated in bladder carcinoma and embryo, influencing cell growth and promoting invasion. FEBS Lett. 2008;582:1919-27.

123. Li T, Xiao Y, Huang T. HIF1alphainduced upregulation of IncRNA UCA1 promotes cell growth in osteosarcoma by inactivating the PTEN/AKT signaling pathway. Oncol Rep. 2018:39:1072-80.

124. McCarty G, Loeb DM. Hypoxia-sensitive epigenetic regulation of an antisense-oriented IncRNA controls WT1 expression in myeloid leukemia cells. PLoS One. 2015;10:e0119837.

125. Dallosso AR, Hancock AL, Malik S, Salpekar A, King-Underwood L, PritchardJones K, Peters J, Moorwood K, Ward A, Malik KT, Brown KW. Alternately spliced WT1 antisense transcripts interact with WT1 sense RNA and show epigenetic and splicing defects in cancer. RNA. 2007;13:2287-99.

126. Wu F, Gao H, Liu K, Gao B, Ren H, Li Z, Liu F. The IncRNA ZEB2-AS1 is upregulated in gastric cancer and affects cell proliferation and invasion via miR-143-5p/HIF-1alpha axis. Onco Targets Ther. 2019;12:657-67.

127. Lorenzen JM, Thum T. Long noncoding RNAs in kidney and cardiovascular diseases. Nat Rev Nephrol. 2016;12:360-73.

128. El Azzouzi H, Doevendans PA, Sluijter JP. Long non-coding RNAs in heart failure: an obvious Inc. Ann Transl Med. 2016;4:182.

129. Kaur P, Liu F, Tan JR, Lim KY, Sepramaniam S, Karolina DS, Armugam A, Jeyaseelan K. Non-coding RNAs as potential Neuroprotectants against ischemic brain injury. Brain Sci. 2013;3:360-95.
130. Jin Q, Zhao Z, Zhao Q, Yu X, Yan L, Zhang Y, Luo Q, Liu Z. Long noncoding RNAs: emerging roles in pulmonary hypertension. Heart Fail Rev. 2019. https://doi.org/10.1007/s10741-019-09866-2.

131. Zhou H, Wang B, Yang YX, Jia QJ, Zhang A, Qi ZW, Zhang JP. Long noncoding RNAs in pathological cardiac remodeling: a review of the update literature. Biomed Res Int. 2019;2019:7159592.

132. Haddad G, Kolling M, Lorenzen JM. The hypoxic kidney: pathogenesis and noncoding RNA-based therapeutic strategies. Swiss Med Wkly. 2019;149: w14703.

133. Qiu JJ, Lin XJ, Zheng TT, Tang XY, Zhang Y, Hua KQ. The Exosomal long noncoding RNA aHIF is upregulated in serum from patients with endometriosis and promotes angiogenesis in endometriosis. Reprod Sci. 2019;26:1590-602.

134. Lang HL, Hu GW, Zhang B, Kuang W, Chen Y, Wu L, Xu GH. Glioma cells enhance angiogenesis and inhibit endothelial cell apoptosis through the release of exosomes that contain long non-coding RNA CCAT2. Oncol Rep. 2017;38:785-98.

135. Chen F, Chen J, Yang L, Liu J, Zhang X, Zhang Y, Tu Q, Yin D, Lin D, Wong P-P, Huang D, Xing Y, Zhao J, Li M, Liu Q, Su F, Su S, Song E. Extracellular vesicle-packaged HIF-1a-stabilizing IncRNA from tumour-associated macrophages regulates aerobic glycolysis of breast cancer cells. Nat Cell Biol. 2019;21:498-510.

136. Guo K, Yao J, Yu Q, Li Z, Huang H, Cheng J, Wang Z, Zhu Y. The expression pattern of long non-coding RNA PVT1 in tumor tissues and in extracellular vesicles of colorectal cancer correlates with cancer progression. Tumour Biol. 2017;39:1010428317699122.

137. Xue M, Chen W, Xiang A, Wang R, Chen H, Pan J, Pang H, An H, Wang X, Hou H, Li X. Hypoxic exosomes facilitate bladder tumor growth and development through transferring long non-coding RNA-UCA1. Mol Cancer. 2017;16:143.

138. Quinn JJ, Chang HY. Unique features of long non-coding RNA biogenesis and function. Nat Rev Genet. 2016;17:47-62.

139. Baek JH, Mahon PC, Oh J, Kelly B, Krishnamachary B, Pearson M, Chan DA, Giaccia AJ, Semenza GL. OS-9 interacts with hypoxia-inducible factor 1alpha and prolyl hydroxylases to promote oxygen-dependent degradation of HIF1alpha. Mol Cell. 2005;17:503-12.

140. Ma MZ, Kong X, Weng MZ, Zhang MD, Qin YY, Gong W, Zhang WJ, Quan ZW. Long non-coding RNA-LET is a positive prognostic factor and exhibits tumor-suppressive activity in gallbladder cancer. Mol Carcinog. 2015;54: 1397-406.

141. Kuwano Y, Pullmann R Jr, Marasa BS, Abdelmohsen K, Lee EK, Yang X, Martindale JL, Zhan M, Gorospe M. NF90 selectively represses the translation of target mRNAs bearing an AU-rich signature motif. Nucleic Acids Res. 2010;38:225-38.

142. Bertozzi D, lurlaro R, Sordet O, Marinello J, Zaffaroni N, Capranico G. Characterization of novel antisense HIF-1alpha transcripts in human cancers. Cell Cycle. 2011;10:3189-97.

143. Chen WM, Huang MD, Kong R, Xu TP, Zhang EB, Xia R, Sun M, De W, Shu $\mathrm{YQ}$. Antisense long noncoding RNA HIF1A-AS2 is upregulated in gastric Cancer and associated with poor prognosis. Dig Dis Sci. 2015;60:1655-62.

144. Ip JY, Nakagawa S. Long non-coding RNAs in nuclear bodies. Develop Growth Differ. 2012;54:44-54.

145. Gutschner T, Hammerle M, Diederichs S. MALAT1 -- a paradigm for long noncoding RNA function in cancer. J Mol Med (Berl). 2013;91:791-801.

146. Hung CL, Wang LY, Yu YL, Chen HW, Srivastava S, Petrovics G, Kung HJ. A long noncoding RNA connects c-Myc to tumor metabolism. Proc Natl Acad Sci U S A. 2014;111:18697-702.

147. van Niel G, D'Angelo G, Raposo G. Shedding light on the cell biology of extracellular vesicles. Nat Rev Mol Cell Biol. 2018;19:213-28.

148. Yousefi H, Maheronnaghsh M, Molaei F, Mashouri L, Reza Aref A, Momeny M, Alahari SK. Long noncoding RNAs and exosomal IncRNAs: classification, and mechanisms in breast cancer metastasis and drug resistance. Oncogene. 2020;39:953-74.

149. Huang X, Yuan T, Tschannen M, Sun Z, Jacob H, Du M, Liang M, Dittmar RL, Liu Y, Liang M, Kohli M, Thibodeau SN, Boardman L, Wang L. Characterization of human plasma-derived exosomal RNAs by deep sequencing. BMC Genomics. 2013;14:319.

150. Chen F, Chen J, Yang L, Liu J, Zhang X, Zhang Y, Tu Q, Yin D, Lin D, Wong PP, Huang D, Xing Y, Zhao J, Li M, Liu Q, Su F, Su S, Song E. Extracellular vesicle-packaged HIF-1alpha-stabilizing IncRNA from tumour-associated 
macrophages regulates aerobic glycolysis of breast cancer cells. Nat Cell Biol. 2019;21:498-510.

151. Naderi-Meshkin H, Lai X, Amirkhah R, Vera J, Rasko JEJ, Schmitz U. Exosomal IncRNAs and cancer: connecting the missing links. Bioinformatics. 2019;35: $352-60$

152. Henze AT, Mazzone M. The impact of hypoxia on tumor-associated macrophages. J Clin Invest. 2016;126:3672-9.

153. Derderian C, Orunmuyi AT, Olapade-Olaopa EO, Ogunwobi OO. PVT1 signaling is a mediator of Cancer progression. Frontiers Oncol. 2019;9:502.

154. Wang C, Han C, Zhang Y, Liu F. LncRNA PVT1 regulate expression of HIF1a via functioning as ceRNA for miR-199a-5p in non-small cell lung cancer under hypoxia. Mol Med Rep. 2017;17:1105-10.

155. Zheng Y, Tian X, Wang T, Xia X, Cao F, Tian J, Xu P, Ma J, Xu H, Wang S. Long noncoding RNA Pvt1 regulates the immunosuppression activity of granulocytic myeloid-derived suppressor cells in tumor-bearing mice. Mol Cancer. 2019;18:61.

156. Berrondo C, Flax J, Kucherov V, Siebert A, Osinski T, Rosenberg A, Fucile C, Richheimer S, Beckham CJ. Expression of the long non-coding RNA HOTAIR correlates with disease progression in bladder Cancer and is contained in bladder Cancer patient urinary exosomes. PLoS One. 2016;11:e0147236.

157. Mao Y, Wang YM, Dong LX, Zhang YJ, Zhang YQ, Wang C, Zhang Q, Yang S, Cao LY, Zhang XY, Li X, Fu ZZ. Hypoxic exosomes facilitate angiogenesis and metastasis in esophageal squamous cell carcinoma through altering the phenotype and transcriptome of endothelial cells. J Exp Clin Canc Res. 2019;38:389.

158. Kucharzewska P, Christianson HC, Welch JE, Svensson KJ, Fredlund E, Ringner M, Morgelin M, Bourseau-Guilmain E, Bengzon J, Belting M. Exosomes reflect the hypoxic status of glioma cells and mediate hypoxiadependent activation of vascular cells during tumor development. Proc Natl Acad Sci U S A. 2013;110:7312-7.

159. Wang J, Yang K, Yuan W, Gao Z. Determination of serum Exosomal H19 as a noninvasive biomarker for bladder Cancer diagnosis and prognosis. Med Sci Monitor. 2018;24:9307-16.

160. Wei JT, Feng Z, Partin AW, Brown E, Thompson I, Sokoll L, Chan DW, Lotan Y, Kibel AS, Busby JE, Bidair M, Lin DW, Taneja SS, Viterbo R, Joon AY, Dahlgren J, Kagan J, Srivastava S, Sanda MG. Can urinary PCA3 supplement PSA in the early detection of prostate Cancer? J Clin Oncol. 2014;32:4066-72.

161. Qiu GZ, Jin MZ, Dai JX, Sun W, Feng JH, Jin WL. Reprogramming of the tumor in the hypoxic niche: the emerging concept and associated therapeutic strategies. Trends Pharmacol Sci. 2017:38:669-86.

162. Dewhirst MW. A potential solution for eliminating hypoxia as a cause for radioresistance. Proc Natl Acad Sci U S A. 2018;115:10548-50.

163. Hughes VS, Wiggins JM, Siemann DW. Tumor oxygenation and cancer therapy-then and now. Br J Radiol. 2019;92:20170955.

164. Milosevic M, Warde P, Menard C, Chung P, Toi A, Ishkanian A, McLean M, Pintilie M, Sykes J, Gospodarowicz M, Catton C, Hill RP, Bristow R. Tumor hypoxia predicts biochemical failure following radiotherapy for clinically localized prostate cancer. Clin Cancer Res. 2012;18:2108-14.

165. Strese S, Fryknas M, Larsson R, Gullbo J. Effects of hypoxia on human cancer cell line chemosensitivity. BMC Cancer. 2013;13:331.

166. Teicher BA, Lazo JS, Sartorelli AC. Classification of antineoplastic agents by their selective toxicities toward oxygenated and hypoxic tumor cells. Cancer Res. 1981;41:73-81.

167. Hatfield SM, Sitkovsky M. A2A adenosine receptor antagonists to weaken the hypoxia-HIF-1alpha driven immunosuppression and improve immunotherapies of cancer. Curr Opin Pharmacol. 2016;29:90-6.

168. Hatfield SM, Kjaergaard J, Lukashev D, Schreiber TH, Belikoff B, Abbott R, Sethumadhavan S, Philbrook P, Ko K, Cannici R, Thayer M, Rodig S, Kutok JL, Jackson EK, Karger B, Podack ER, Ohta A, Sitkovsky MV. Immunological mechanisms of the antitumor effects of supplemental oxygenation. Sci Transl Med. 2015;7:277ra30

169. Facciabene A, Peng X, Hagemann IS, Balint K, Barchetti A, Wang LP, Gimotty PA, Gilks CB, Lal P, Zhang L, Coukos G. Tumour hypoxia promotes tolerance and angiogenesis via CCL28 and T(reg) cells. Nature. 2011;475:226-30.

170. Noman MZ, Desantis G, Janji B, Hasmim M, Karray S, Dessen P, Bronte V, Chouaib S. PD-L1 is a novel direct target of HIF-1a, and its blockade under hypoxia enhanced MDSC-mediated T cell activation. J Exp Medicine. 2014; 211:781-90.

171. Gillies RM, Robinson SP, McPhail LD, Carter ND, Murray JF. Immunohistochemical assessment of intrinsic and extrinsic markers of hypoxia in reproductive tissue: differential expression of HIF1alpha and HIF2alpha in rat oviduct and endometrium. J Mol Histol. 2011;42:341-54.

172. Kim BW, Cho H, Chung JY, Conway C, Ylaya K, Kim JH, Hewitt SM. Prognostic assessment of hypoxia and metabolic markers in cervical cancer using automated digital image analysis of immunohistochemistry. J Transl Med. 2013;11:185.

173. Darfeuille F, Reigadas S, Hansen JB, Orum H, Di Primo C, Toulme JJ. Aptamers targeted to an RNA hairpin show improved specificity compared to that of complementary oligonucleotides. Biochemistry-us. 2006;45:12076-82.

174. Özeş AR, Wang Y, Zong X, Fang F, Pilrose J, Nephew KP. Therapeutic targeting using tumor specific peptides inhibits long non-coding RNA HOTAIR activity in ovarian and breast cancer. Sci Rep-uk. 2017;7:894.

175. Alfranca A. VEGF therapy: a timely retreat. Cardiovasc Res. 2009;83:611-2.

176. Benej M, Hong X, Vibhute S, Scott S, Wu J, Graves E, Le QT, Koong AC Giaccia AJ, Yu B, Chen CS, Papandreou I, Denko NC. Papaverine and its derivatives radiosensitize solid tumors by inhibiting mitochondrial metabolism. Proc Natl Acad Sci U S A. 2018;115:10756-61.

177. Kopp F, Mendell JT. Functional classification and experimental dissection of long noncoding RNAs. Cell. 2018;172:393-407.

178. Cao M, Zhao J, Hu G. Genome-wide methods for investigating long noncoding RNAs. Biomed Pharmacother. 2019:111:395-401.

179. Ortiz-Barahona A, Villar D, Pescador N, Amigo J, del Peso L. Genome-wide identification of hypoxia-inducible factor binding sites and target genes by a probabilistic model integrating transcription-profiling data and in silico binding site prediction. Nucleic Acids Res. 2010;38:2332-45.

180. Grampp S, Platt JL, Lauer V, Salama R, Kranz F, Neumann VK, Wach S, Stohr C, Hartmann A, Eckardt KU, Ratcliffe PJ, Mole DR, Schodel J. Genetic variation at the 8q24.21 renal cancer susceptibility locus affects HIF binding to a MYC enhancer. Nat Commun. 2016;7:13183.

181. Grampp S, Schmid V, Salama R, Lauer V, Kranz F, Platt JL, Smythies J, Choudhry H, Goppelt-Struebe M, Ratcliffe PJ, Mole DR, Schodel J. Multiple renal cancer susceptibility polymorphisms modulate the HIF pathway. PLoS Genet. 2017;13:e1006872.

182. Van Roosbroeck K, Pollet J, Calin GA. miRNAs and long noncoding RNAs as biomarkers in human diseases. Expert Rev Mol Diagn. 2013;13:183-204.

\section{Publisher's Note}

Springer Nature remains neutral with regard to jurisdictional claims in published maps and institutional affiliations.

Ready to submit your research? Choose BMC and benefit from:

- fast, convenient online submission

- thorough peer review by experienced researchers in your field

- rapid publication on acceptance

- support for research data, including large and complex data types

- gold Open Access which fosters wider collaboration and increased citations

- maximum visibility for your research: over $100 \mathrm{M}$ website views per year

At BMC, research is always in progress.

Learn more biomedcentral.com/submission 